\title{
A PRIMER OF FORESTRY
}

PART II-PRACIICAL FORESTRY

\section{GHFORD PUNCHOT}

Batletin 24

Bureau of Forestry

U. S. Dept, of Agriculture

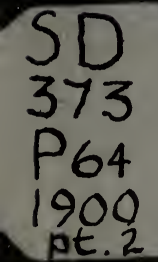


I

- 



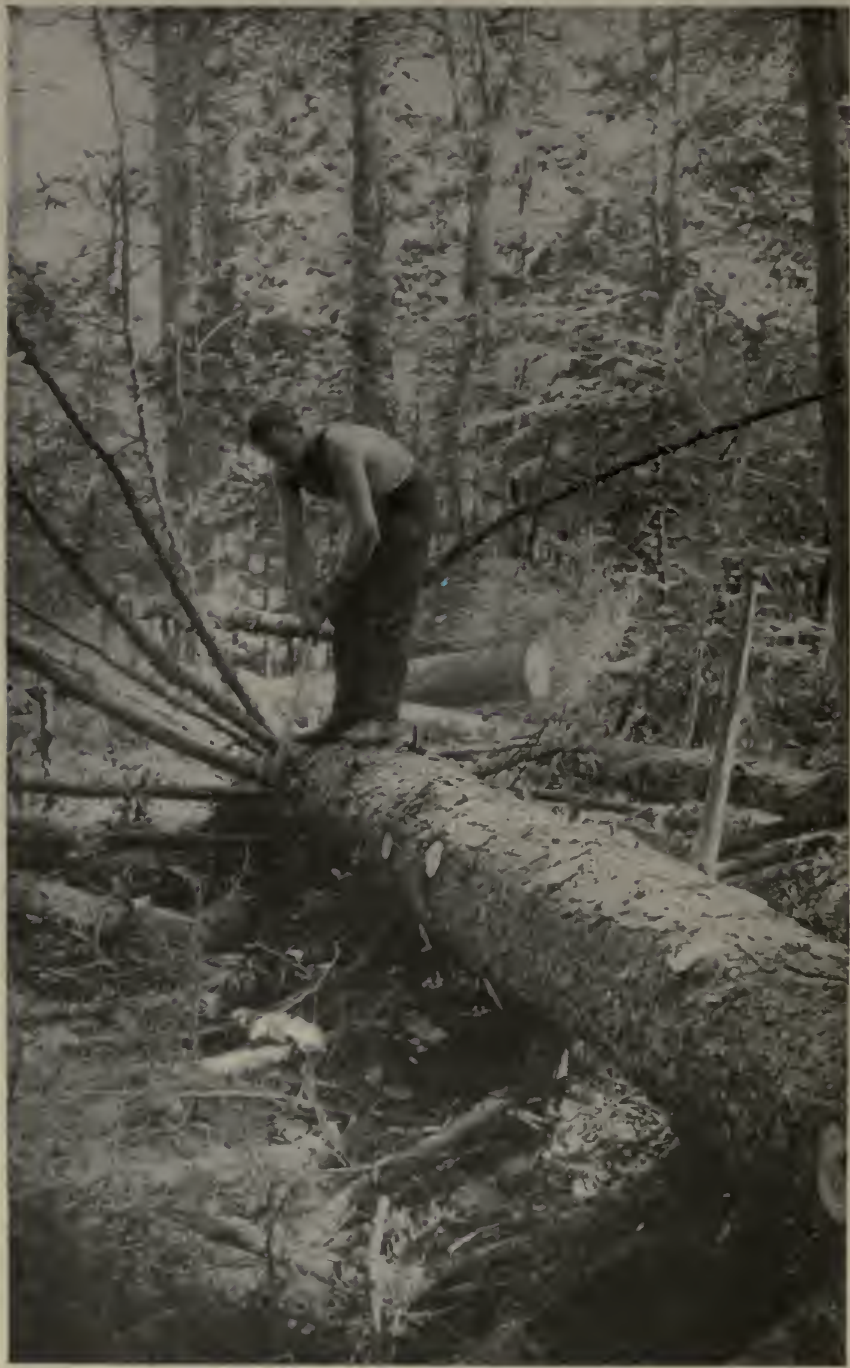


Gor.sue U.S. Fores/ service

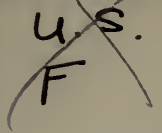

BULletin No. 24, PART II.

U. S. DEPARTMENT OF AGRIOULTURE. BUREAU OF FORESTRY.

\section{A PRIMER OF FORESTRY.}

Part II.--PRACTICAI FORESTRY.

By GIFFORI PINCHOT, FORESTER!'

WASHINGTON:

GOVERNMENT PRINTING OFFICE. 1905 . 


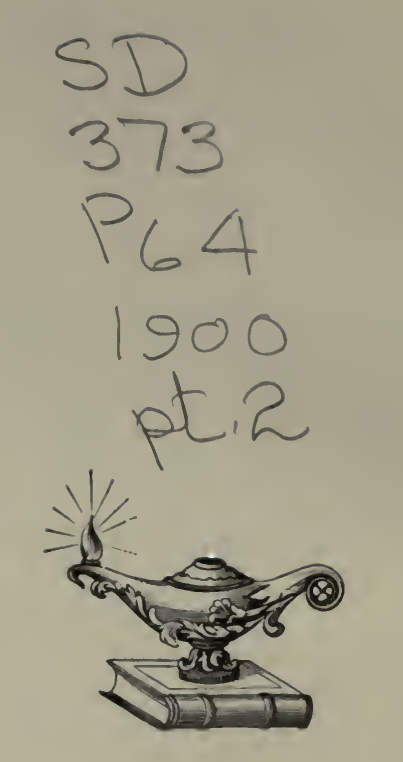




\section{LETTER OF TRANSMITTAL.}

\section{U. S. Department of Agriculture,}

Bureau of Forestry, Washington, D. C., June 26, 1903.

SIR: I have the honor to transmit herewith the manuscript of the second half of "A Primer of Forestry," and to recommend its publication as Bulletin No. 24, Part II, of this Bureau. The second part (Practical Forestry) deals with the practice of forestry, with work in the woods, and with the relation of the forest to the weather and the streams, and concludes with a short account of forestry at home and abroad.

The illustrations are from photographs in the collection of the Bureau of Forestry, some of which were contributed by gentlemen not members of the Bureau, to whom I desire to express my acknowledgments.

Respectfully,

\section{Gifford Pinchot,}

\section{Forester.}

Hon. Jayes' WiLson,

Secretary of Agriculture. 


\section{Digitized by the Internet Archive in 2007 with funding from Microsoft Corporation}




\section{CONTENTS.}

Chapter I. - The Practice of Forestry ............. 7

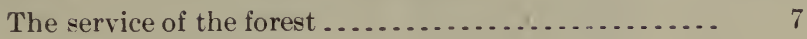

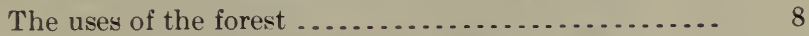

Four requirements for the best service............ 11

The yield of a forest........................ 14

Silvicultural systems ........................ 18

Simple coppice ......................... 19

Stored coppice.............................. 21

Seed or high forest....................... 22

Regular seed forest........................ 23

Two-storied seed forest . . . . . . . . . . . . . . . . . 27

Selection forest .......................... 28

Localized selection . . . . . . . . . . . . . . . . . . . 30

The group system ......................... 33

The strip system........................... 35

Improvement cuttings..................... 36

Chapter II.-Work in the Woods................ 38

Conservative lumbering ....................... 40

Conservative lumbering and ordinary lumbering.. 41

Felling the trees....................... 42

Swamping and sawing...................... 45

Skidding ............................... 47

Transportation .......................... 49

At the mills .............................. 51

Waste in lumbering......................... 53

Planting ................................... 54 
Chapter III.-The Weatier axi the Streams....... 56

Forests and climate ....................... 57

Effect of forest cover on temperature............ 59

Extremes of heat and cold .................... 61

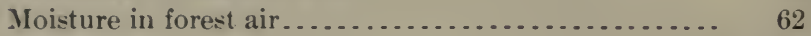

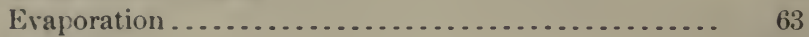

Rainfall ................................. 66

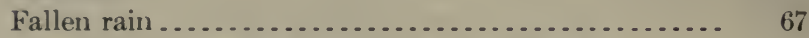

Chapter IV.-Forestry Abroad and at Home........ 74

Forestry abroad .......................... 74

The forest in early times .................. $\quad 75$

Modern forestry .......................... $\quad 75$

Germany ......................... 77

France ............................ 77

Switzerland ........................ 78

British India ...................... 80

Forestry at home .......................... 81

The settler and the forest................. 82

First steps in forestry .................... 83

The public domain ...................... 85

Federal forest reserves ................. 85

State forestry ......................... 87

\section{ILLUSTRATIONS.}

Plates $-2 .+2$

Text figures ................................. $\quad 47$ 


\section{A PRIMER OF FORESTRY.}

\section{CHAPTER I.}

\section{THE PRACTICE OF FORESTRY.}

THE SERVICE OF THF FOREST.

Next to the earth itself the forest is the most useful servant of man. Not only does it sustain and regulate the streams, moderate the winds, and beautify the land, but it also supplies wood, the most widely used of all materials. Its uses are numberless, and the demands which are made upon it by mankind are numberless also. It is essential to the well-being of mankind that these demands should be met. They must be met steadily, fully, and at the right time if the forest is to give its best service. The object of practical forestry is precisely to make the forest render its best service to man in such a way as to increase rather than to diminish its usefulness in the future. Forest management and conservative lumbering are other names for practical forestry. Under whatever name it may be known, practical forestry means both the use and the preservation of the forest. 
THE USES OF THE FOREST.

A forest. large or snall, may render its service in many ways. It may reach its highest usefulness by standiug as a safeguard against floods, winds, snow slides, moving sands, or especially against the dearth of water in the streams. A forest used in this way is called a protection forest, and is usually found in the mountains, or on bleak, open plains, or by the sea.

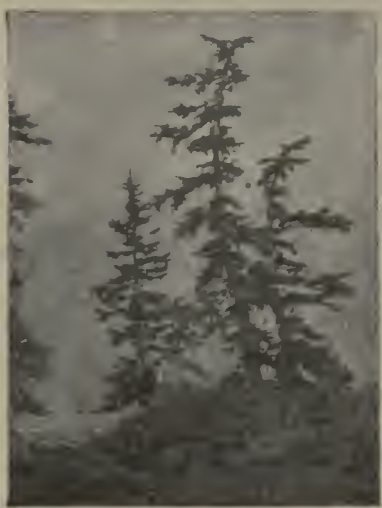

Frg. 1.-Alpine hemlock in a protection forest. Cascade Mountains, Wushington.
Forests which protect the headwaters of streams used for irrigation, and many of the larger windbreaks of the Western plains, are protection forests. The Adirondack and Catskill woodlands were regarded as protection forests by the people of the State of New York when they forbade, in the constitution of 1895 , the felling, destruction. or removal of any trees from the State Forest Preserve.

A farmer living directly on the produce of his land would find his woodlot most useful to him when it supplied the largest amount of wood for his peculiar needs, or the best grazing for his cattle. 1 railroad holding land which it did not wish to sell would perhaps find it most useful when it produced the greatest number of ties and bridge timbers. In both cases the forest would render its best service by producing the 


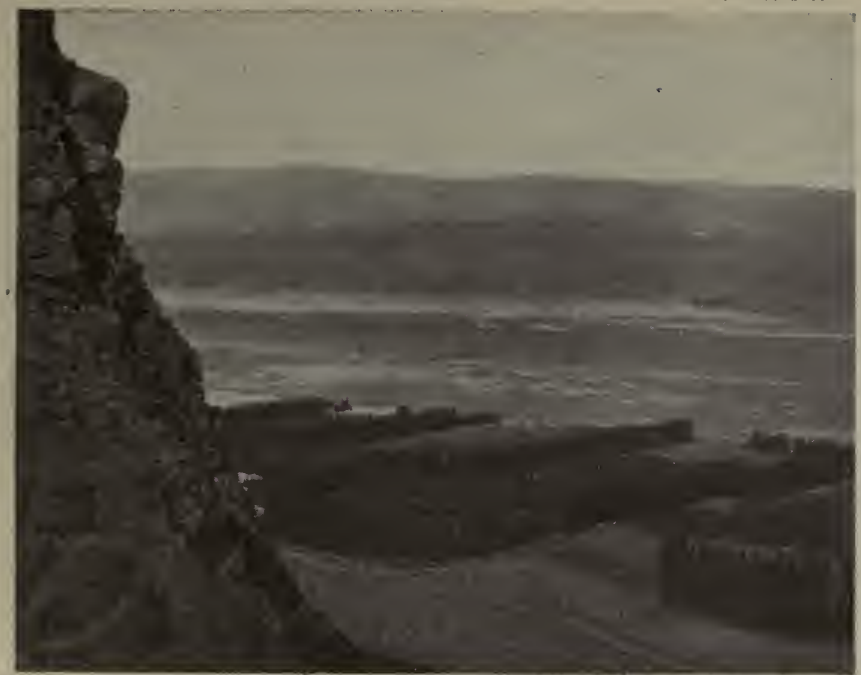

Fi3. 1.-Windbreaks of lombardy Poplar, intended to Protect Orchard Trees against Wind and Moving Sand. Near The Dalles, Oregon.

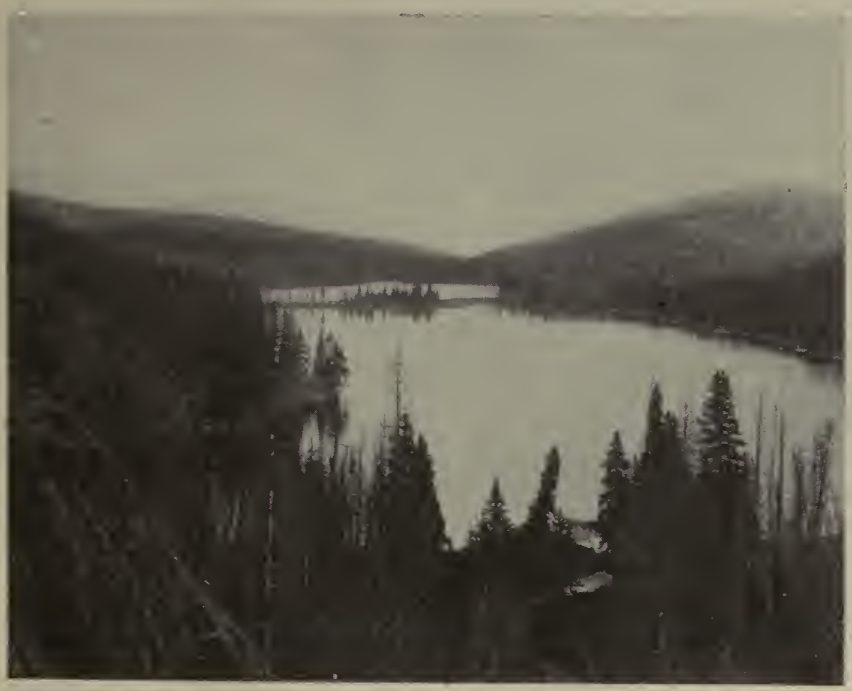

Fig. 2.-Protection forest about a Lake. Adirondack Mountains, New York. 



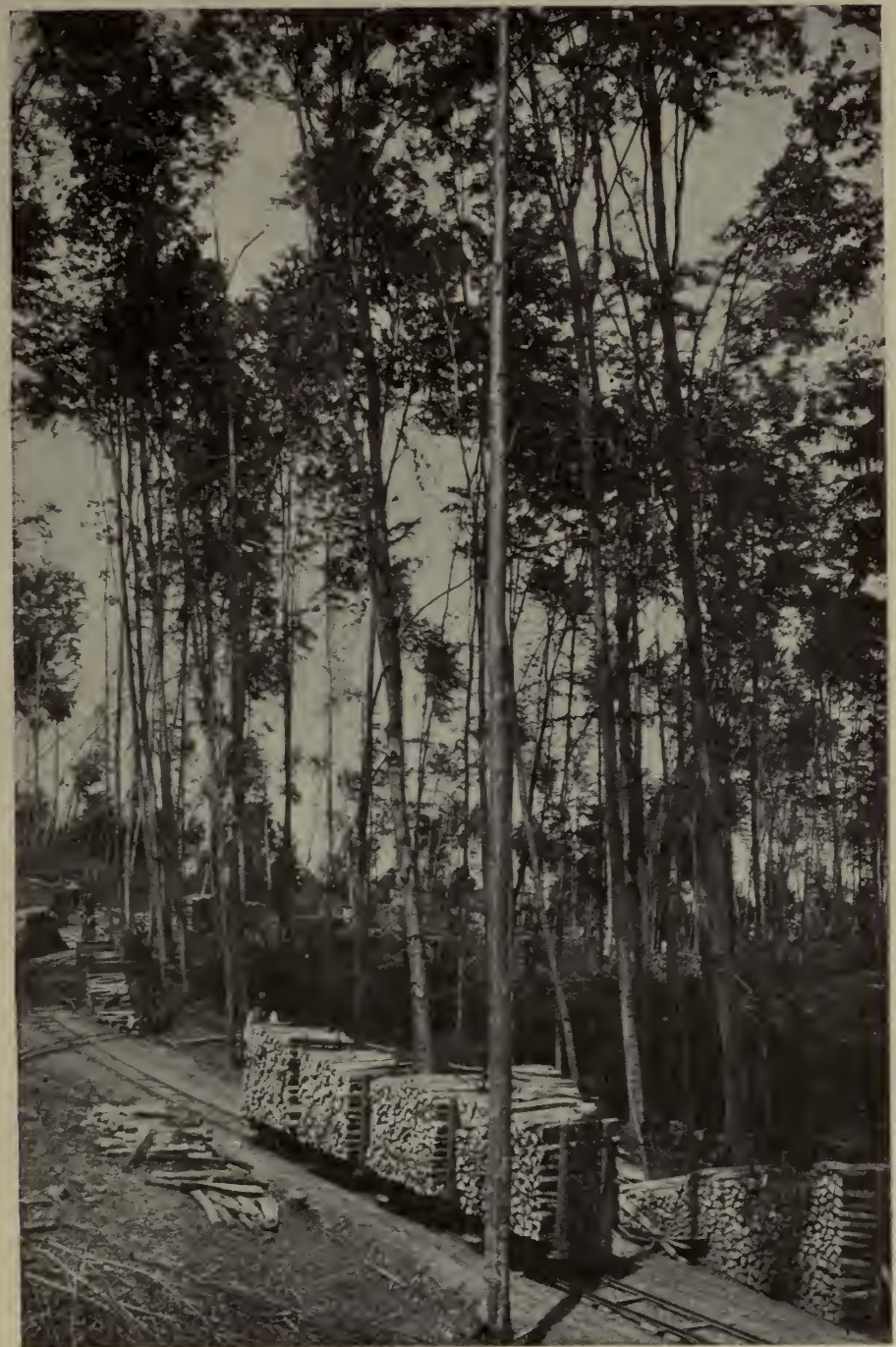

Scene in the Sihlwald, the Town Forest of Zurich, SWitzerland, from which its OWner Desires the Greatest net Money Return. 

greatest quantity of valuable material. This is the central idea upon which the national forests of France are managed.

The greatest return in money may be the service most desired of the forest. If a farmer wished to sell the product of his woodlot instead of consuming it

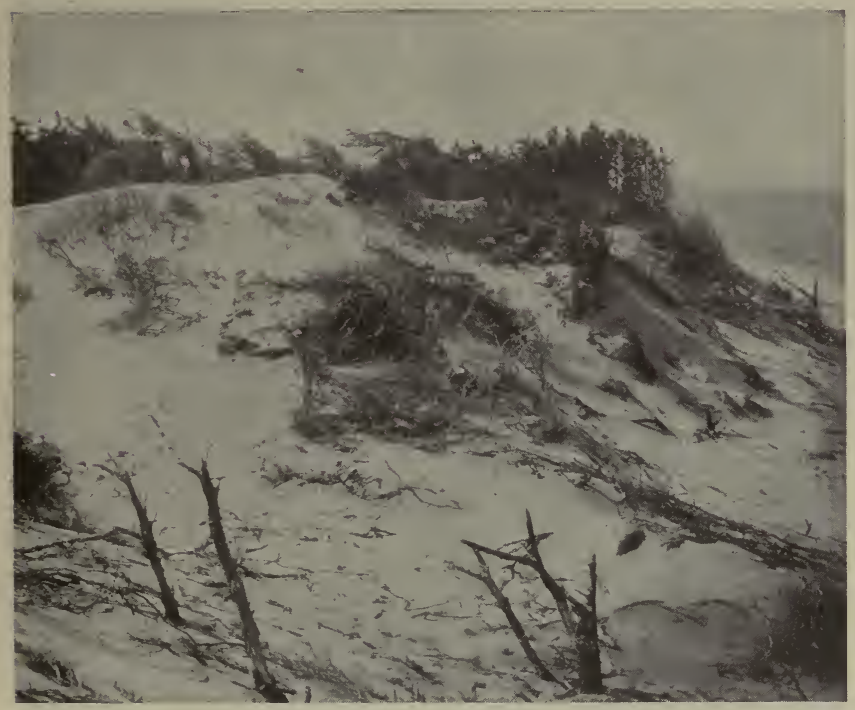

FIG. 2.-Moving sand dunes near Cape May, N. J., where once the whaling town of Portsmouth stood. In the foreground, red cedars buried and partly uncovered by the wind.

himself, his woodland would be useful to him just in proportion to its net yield in money. This is true also in the case of any owner of a forest who wishes to dispose of its product, but who can not, or will not, sell the forest itself. State forests, like those in the 
Adirondacks, often render their best service, in addition to their usefulness as protection forests, by producing the greatest net money return.

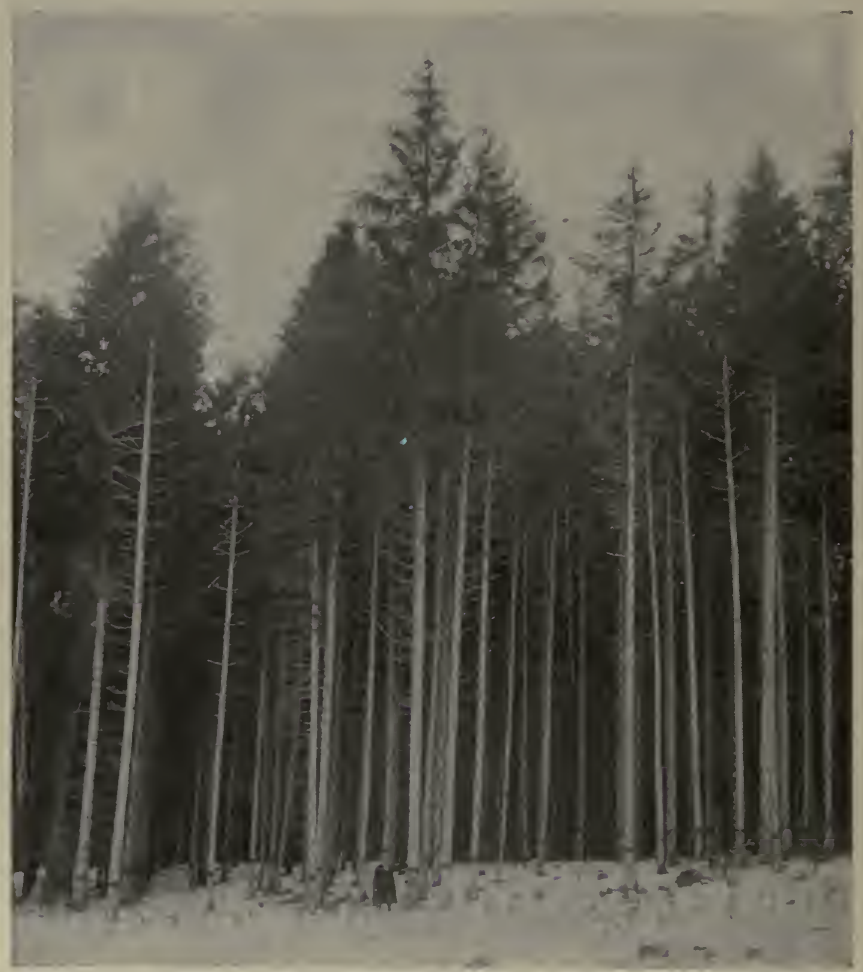

Fis;. 3.-An exceedingly productive spruce forest in Bavaria.

Regarded as an investment of capital, a forest is most useful when it yields the highest rate of interest. A forest whose owner conld sell it if he chose, but prefers to hold it as productive capital, is useful in pro- 
portion to the interest it yields on the money invested in it. Thus, an acre of sprout land may be worth only $\$ 5$, while the investment in adjoining land stocked with old trees may be $\$ 50$ an acre. This is the view which controls the management of State forests in Germany. Lumbermen also regard timberland as an investment, but usually they take no care except for the yield at the moment. They disregard the future yield altogether, and in consequence the forest loses its capital value, or may even be totally destroyed. Well managed forests, on the other hand, are made to yield their service always without endangering the future yield, and usually to its great advantage. Like the plant of a successful manufacturer, a forest should increase in productiveness and value year by year.

Under various circumstances, then, a forest may yield its best return in protection, in wood, grass, or other forest products, in money, or in interest on the capital it represents. But whichever of these ways of using the forest may be chosen in any given case, the fundamental idea in forestry is that of perpetuation by wise use; that is, of making the forest yield the best service possible at the present in such a way that its usefulness in the future will not be diminished, but rather increased.

FOUR REQUIREMENTS FOR THE BEST SERVICE.

A forest well managed under the methods of practical forestry will yield a return in one of the ways just mentioned. There are, however, four things a forest must have before it can be in condition to render the best service. 
The first of these is protection, especially against fire, overgrazing, and thieves, for without such protection no investment is secure and the most skillful management is of little effect.

The second is strong and abundant reproduction. A forest without young growth is like a family without children. It will speedily die out.

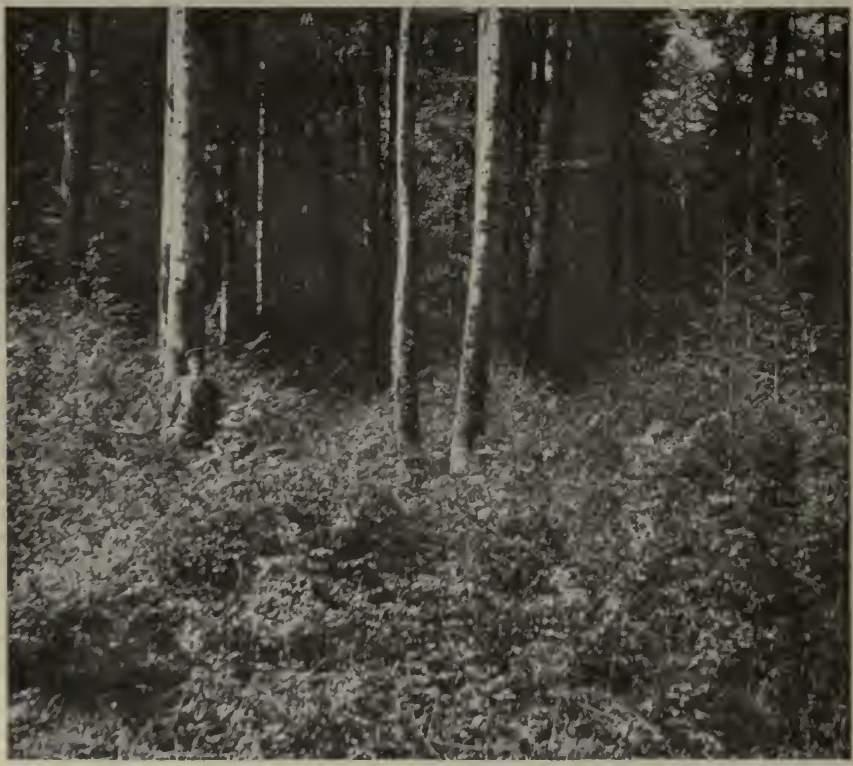

FIG. 4.-Vigorous reproduction along the edge of a forest. Germany.

The third requirement is a regular supply of trees ripe for the ax. This can be secured only by the right proportion of each of the smaller sizes constantly coming on in the growing forest. Thus, a farmer in 
need of fuel might be much inconvenienced to find no trees on his woodlot big enough for cordwood, and it would not help him to know that twenty years later he would have an oversupply. In the same way a larger forest may yield only a very irregular and unsatisfactory product if at one time there are too many ripe trees and at another too few. For example, if 100 acres become fit to cut this year, and 200 next year. and after that none at all until 500 acres become ripe fifteen year's later, it is easy to see that the yield would come at very irregular and perhaps very inconrenient times. But a forest of 10,000 acres, composed of 100 evenaged groups of trees of every age from 1 to 100 years, each group 100 acres in extent (see fig. 5),

\begin{tabular}{|c|c|c|c|c|c|c|c|c|c|}
\hline 10 & 9 & 8 & 7 & 6 & 5 & 4 & 3 & 2 & 1 \\
\hline 11 & 12 & 13 & 14 & 15 & 16 & 17 & 18 & 19 & 20 \\
\hline 30 & 29 & 28 & 27 & 26 & 25 & 24 & 23 & 22 & 21 \\
\hline 31 & 32 & 33 & 34 & 35 & 36 & 37 & 38 & 39 & 40 \\
\hline 50 & 49 & 48 & 47 & 46 & 45 & 44 & 43 & 42 & 41 \\
\hline 51 & 52 & 53 & 54 & 55 & 56 & 57 & 58 & 59 & 60 \\
\hline 70 & 69 & 68 & 67 & 66 & 65 & 64 & 63 & 62 & 61 \\
\hline 71 & 72 & 73 & 74 & 75 & 76 & 77 & 78 & 79 & 80 \\
\hline 90 & 89 & 88 & 87 & 86 & 85 & 84 & 83 & 82 & 81 \\
\hline 91 & 92 & 93 & 94 & 95 & 96 & 97 & 98 & 99 & 100 \\
\hline
\end{tabular}

Frg. 5.-Diagram of a forest with one hundred even-aged compartments.

would plainly be able to furnish every year 100 acres of 100 -year-old trees ready for the ax. In such a forest the right proportion of young trees would always be coming on.

The fourth requirement is growing space enough for every tree, so that the forest as a whole (see fig. 7) may not only produce wood as fast as possible, but the most valuable sort of wood as well. If the trees stand too far apart, their trunks will be short and thickly covered with branches, the lumber cut from 
them will be full of knots, and its value will be small. If, on the other hand, the trees stand too closely

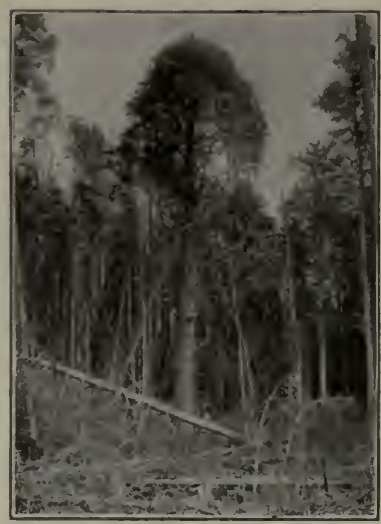

Fig. 6.-A white cedar which has had too much growing space. The tree is large, but full of knots, and will yield very little good lumber. together, although their trunks will be tall and clear of branches, they will be small in diameter, and for that reason low in value. With the right amount of growing space, trees grow both tall and of good diameter. and their trunks supply lumber of higher price because it is wide and clear.

- THE YIELD OF A FOREST.

One of the central ideas of forestry is that the amount of wood taken from any healthy forest and the amount grown

by it should be as nearly equal as possible. If more grows than is cut, then the forest will be filled with overmature, decaying trees; but if more wood is cut than is grown, then the supply of ripe trees will be exhausted, and the value of the forest will decline. 'To make the cut equal to the growth does not mean that the volume of wood grown

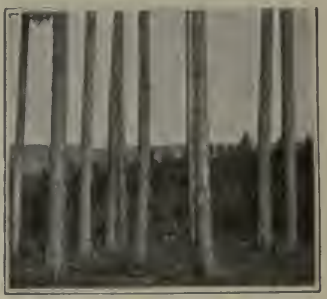

Fig. 7.-Old trees which have had the right amount of growing space to make ('lean trunks and clear lumber. Germany. each year on every acre should be cut from that acre, but that the total growth of all the acres, for one or 
for a number of years, should be cut from the forest in the corresponding period. Thus, if the growth or increase is 100 cords a year, that amount might be harrested yearly by cutting every tree on a small area, by cutting fewer trees per acre on a larger area, by distributing the cut every year over the whole surface of

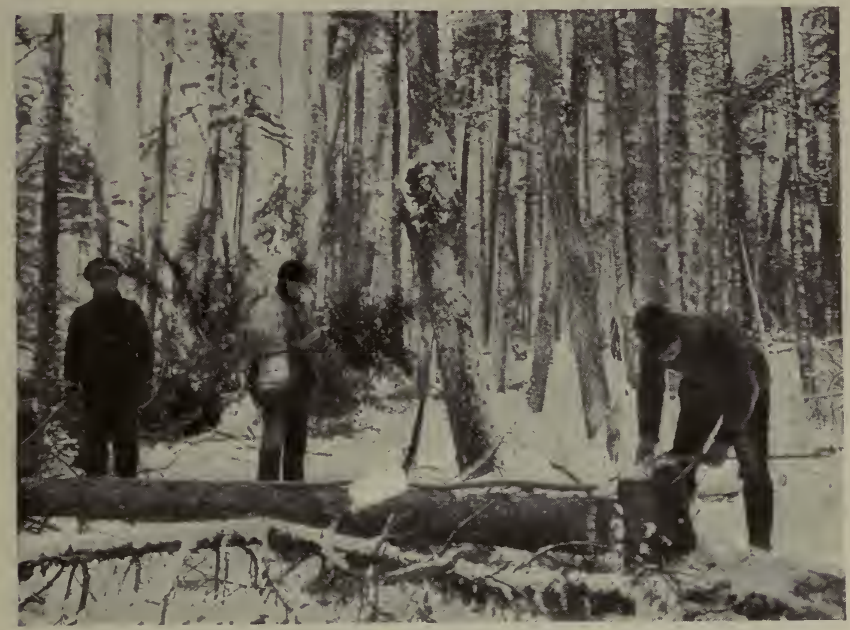

FIG. 8.-Measuring an average tree. Adirondack Mountains, New York.

the forest, or by cutting 1,000 cords in any one of these ways once in ten years.

There are many different methods of finding what is the annual increase of wood in a forest. One of the simplest is to count the number of trees upon an acre and select an average tree, then to cut it down, measure its cubic contents, and find its age by counting the annual rings. That done, the yearly increase 
of the average tree may be found by dividing its cubic contents by the years of its age. Finally, since we have found the yearly increase per tree and the number of trees per acre, it is easy to find the average yearly increase per acre. It is unfortunate that this simple and easy process is not always reliable, because it is hard to find either an average acre or an average tree.

The yield of a forest is the amount of wood that is taken from it in a given time. When a forest is put under conservative management, one of the most important steps is to decide how much timber can safely be taken from it; in other words, to determine the yield. There are three principal ways of doing so.

The first, and the least used, is to fix the yield at a certain number of mature trees. By this plan the yield of a certain forest might be 100 pines, 260 spruces, and 180 hemlocks, each of a given diameter, every year.

The second way is to fix the yield at a certain amount or volume of wood. 'Thus, the yield of a large forest might be fixed at 25,000,000 feet board measure every ten years, and that of another smaller one at 750 cords every year.

The third way is to settle upon a certain number of acres to be cut orer yearly or once in a griven number of years. By this method the yield of a forest of 600 acres might be fixed at 6 acres of mature timber a year, and that of another at 300 acres every twenty-five years. The time between two successive cuttings on the same area must be long enough to allow the young trees left 
standing to mature. That time is found by studying the rate of growth in diameter.

This method of determining the yield by area is much the most practicable of the three for the forests of the United States, and in general it is the simplest and most widely useful of all, because it does away with the

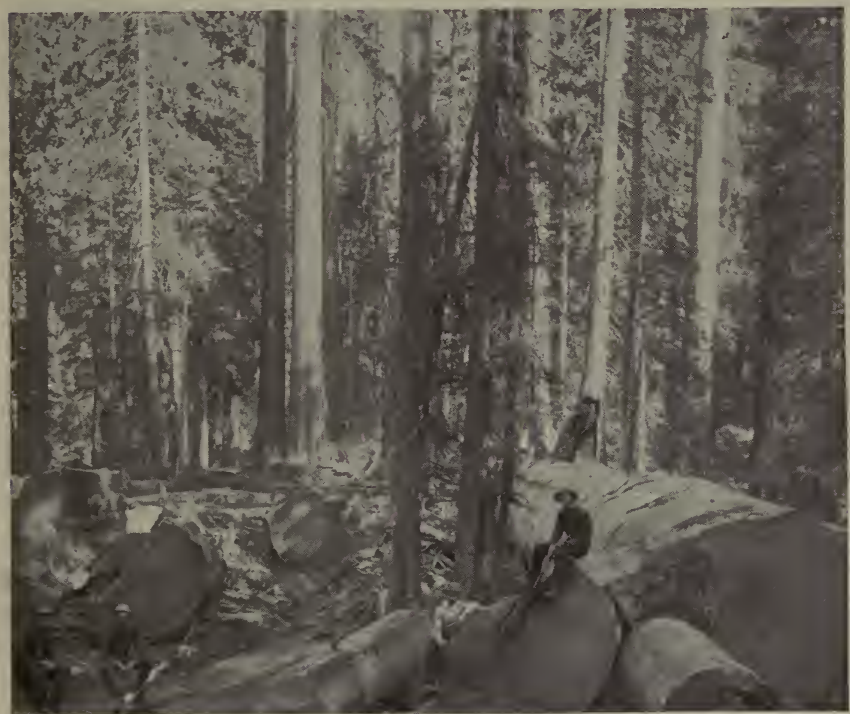

FIG. 9. A forest from which more than the yield is being taken. Big Trees in the Sierra Nevada Mountains, California.

difficult task of determining the yearly increase in wood.

The objects in handling forests are so various that sor etimes no single one of these methods is satisfactor , and then combinations of them are of great use. 
'Thus, by combining the method by volume and the method by area the annual yield of a forest might be established at 250 board feet per acre. This yield might be cut from the forest every year, or it might be allowed to accumulate for twenty years, and then 5,000 board feet per acre might be cut.

\section{SILVICULTURAL SYSTEMS.}

Ifter the yield has been found it must be cut not only without injury to the future value of the forest, but in such a way as to increase its safety and usefulness. To this end certain ways of handling forests, called silvicultural systems, have grown up. They are based on the nature of the forest itself, and are chicfly imitations of what men have seen happen in the forest without their help.

From the point of vien of forest mandgement, one of the prineipal differwes between troes is whether they spring directly from seed or are preluced as sprouts from stumps or root alneady in the cround. A forest composed of seedling trees is culled a Seed Forest, or more commonly but less suitably, a siedling or High Forest. One composed of sprouts is spuken of as a Sprout or Coppice Forest, or, more often, - -imply as Coppice, or as Sprout land. Seed Forepts are usually composed of coniferous trees, which inely sprout, or of broadleaf trees allowed to reach 'nrge size. Sprout Forests are common wherever hroacleaf trees are cut while they are still young. for the sprouting power usually diminishes with age spouts ne rer reach so great a height and diameter $\mathrm{a}$ s bealing trow, although in youth they grow much fastery and they wo 
Bul. 24, Bureau of Forestry, U. S. Dept. of Agr.

Plate IV.

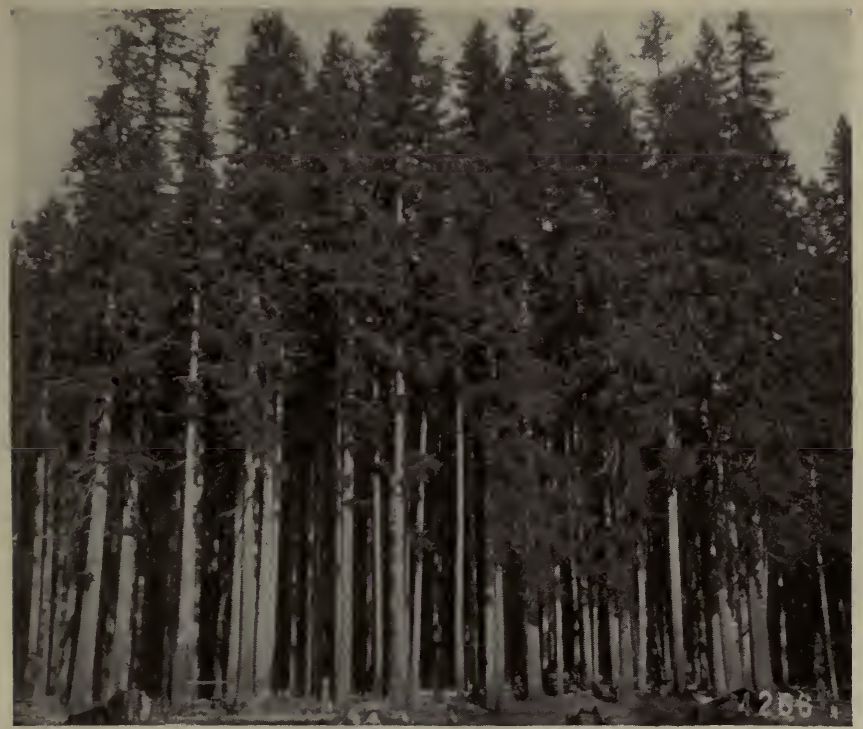

FIG. 1. - SEED FOREST OF FIR IN WASHINGTON.

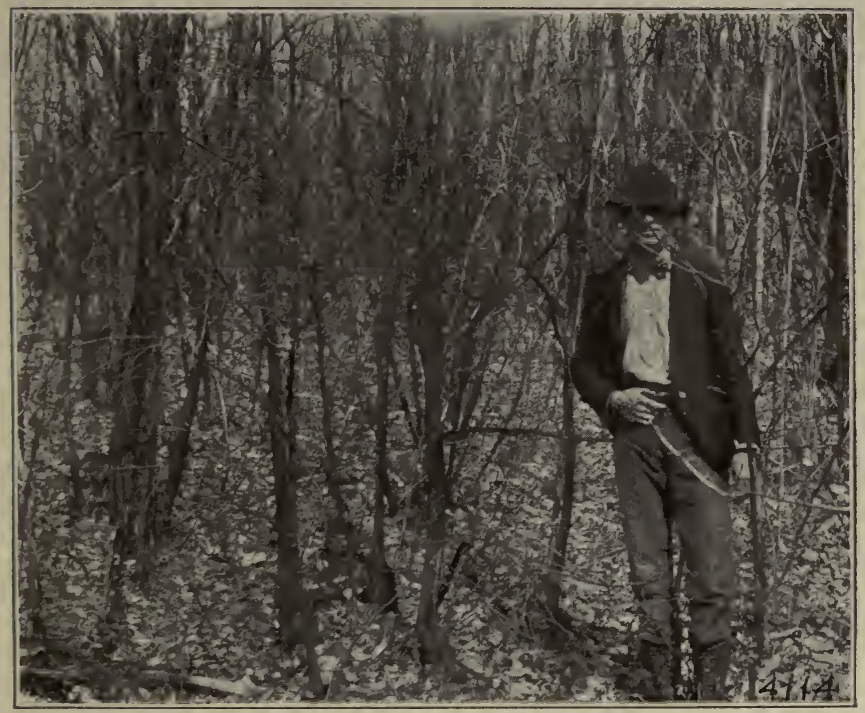

FIG. 2. - SPROUT FOREST SPRINGING UP AFTER A FIRE. 


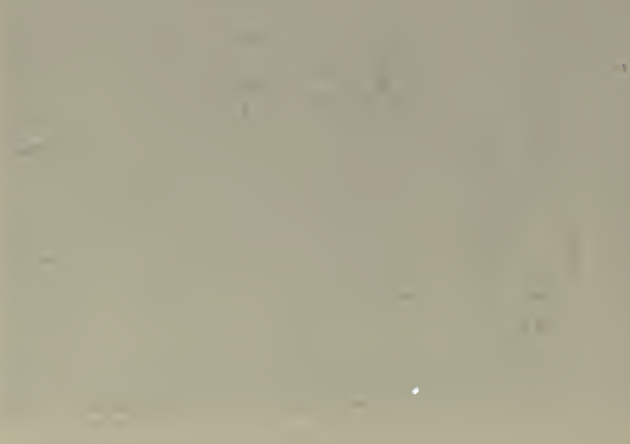


apt to be unsound, because the old stumps decay and infect the sprouts which spring from them.

SIMPLE COPPICE.

It often happens, as in Pennsylvania or New Jersey, that a fire sweeps over the second-growth hardwood lands and kills all the young trees down to the ground; but the roots remain alive, and from them spring young sprouts about the bases of the burned trunks. After several years a second fire may follow and kill back the sprouts again, and other fires may continue at intervals to buin over the land, each followed by a new crop of sprouts. When a farmer does with the ax what is often done by fire he is using the system of Simple Coppice.

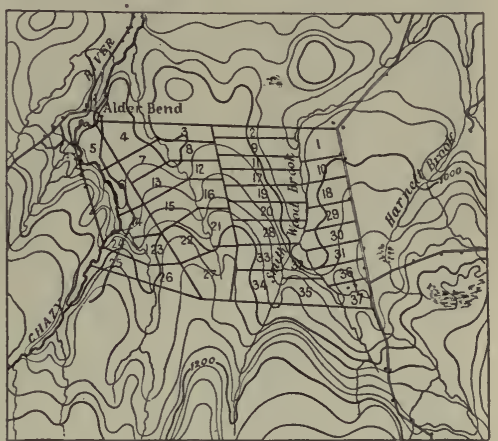

Fig. 10.-Ideal sketch map of a sprout forest managed under the system of Simple Coppice.

Let us suppose a farmer has a woodlot covered principally with chestnut sprouts which he wants to manage for the steady production of railroad ties. He knows that chestnut sprouts are usually large enough for ties at the age of 35 years. In order to insure a steady yield of trees fit for ties, he divides the whole woodlot into thirty-five parts of equal productive capacity, and cuts one part clean every year. All the new sprouts that spring up on the part cut in any year 
are of the same age. At the end of thirty-five years, when the whole woodlot has been cut over, the thirtyfive parts form a series of even-aged groups of sprouts

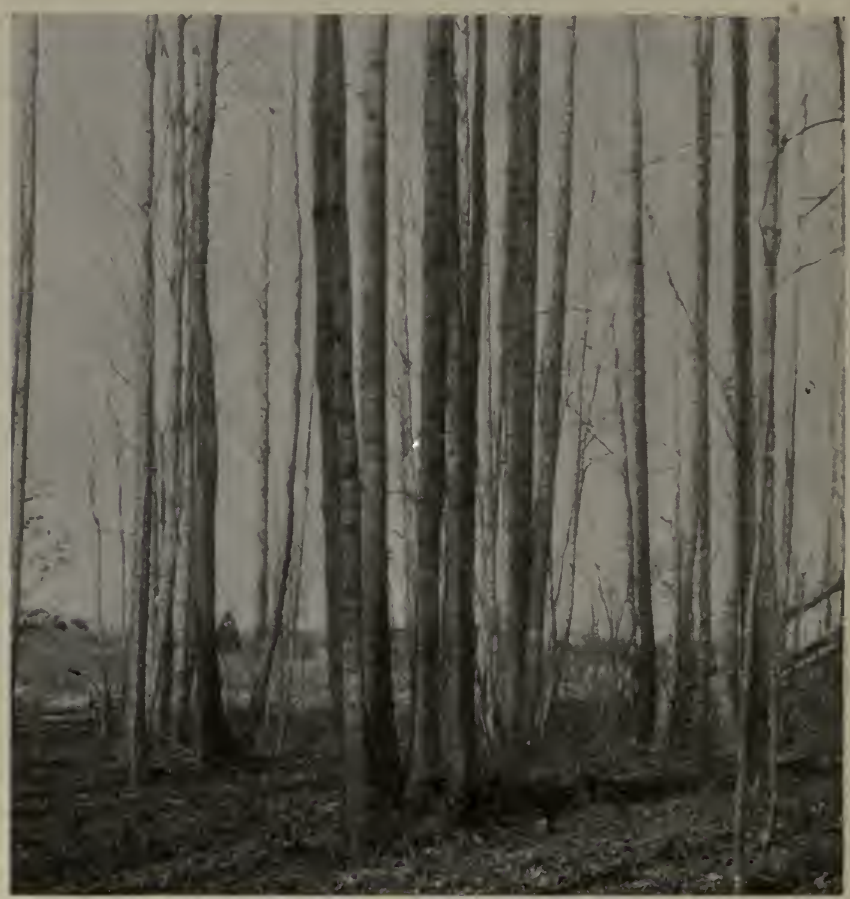

Fig. 11.-Yellow poplar sprout forest in Maryland.

from 1 to 35 year's old. Every year the sprouts on one part reach the age of 35 years and are ready for cutting. Simple Coppice is a very useful silvicultural system. and the easiest of all to apply. The chief requirements for its sucess are good reproduction from the stumps, 
proper thinning (where thinning can be made tc pay), and enough young seedlings among the sprouts to replace exhausted stumps with vigorous young ones. Stumps from which the sprouts have been cut many times finally grow weak and lose their power of sprouting.

In cutting sprouts it is important not to loosen the bark on the stumps, for that impairs their sprouting power, and to make the cut as near the ground as possible. Stumps cut level with the surface sprout best of all. In simple Coppice, well handled, the reproduction takes place of itself without the need of further attention from the forester.

Many thousands of acres of American woodland, especially in New England, New York, Pennsylvania, and New Jersey, and in other places where chestnut is the principal tree, are treated under a rough system of Simple Coppice.

STORED COPPICE.

Among the trees which will produce only fuel, fence posts, or railroad ties there often stand in a woodlot others which would yield much larger returns if they were allowed to reach a greater age and size than the trees about them. If there were some white oaks scattered through the chestnut coppice just described, it might be well to let them grow large enough for the production of high-priced material like quartered oak lumber. In that case it would be necessary at the time of cutting the sprouts to select and leare standing a certain number of white oaks on every acre. As many of them as survived the increased exposure to wind and 
sun following the sudden removal of their neighbors would remain as standards over the young sprouts. The white oak standards thus chosen would remain uncut during two, three, four, or sometimes even five successive crops of sprouts, and would form stout trunks with little taper, clear of branches almost to the full height reached by the sprouts.

This is the silvicultural system called Stored Coppice, or sometimes Coppice under Standards. The successful mamagement of a forest under it depends largely upor. the choice of the standards. They should be seedlings, for seedlings make the best trees, or the most vigorous and healthy sprouts if seedlings can not be found, and they should be distributed as regularly as possible over the ground. The standards should be numerous enough at first to allow for heavy loss from wind and shock when the sprouts are cut away, but they should never be allowed to suppress the lower story of growth.

Stored Coppice is a very useful system where the principal demand is for small material, like fuel, ties, and fencing. but where some large timber also is required. It was dereloped chiefly by the French, who use it with admirable results.

\section{SEEI OR HIGII FOREST.}

By far the most useful and important forests are, as a rule, those which spring directly from seed, such as the pine forests of the Southern States, and the great hardwood forests of the Mississippi Valley. Such forests are called Seed Forests. The Seed Forest systems are of many kinds, some of which are peculiarly adapted for the management of certain forests in the 


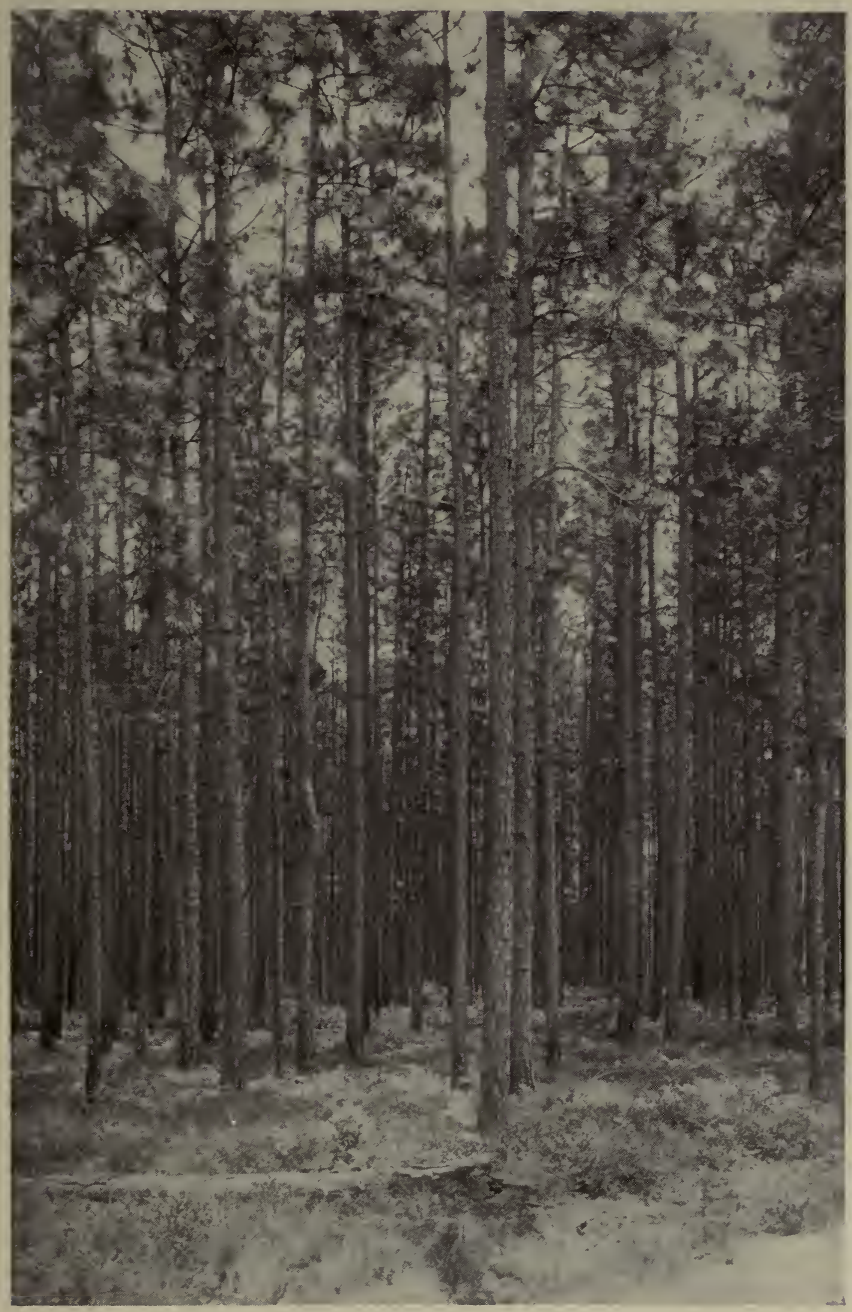




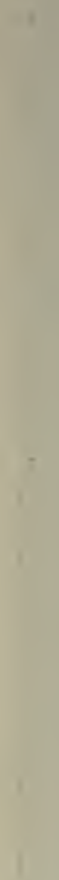

- 
United States. Just as the Sprout Forest systems are chiefly useful to produce fuel, posts, ties, and trees of small size, so the Seed Forest systems are producers of sawlogs and large timbers.

REGLLAR SEED FOREST.

When a tract of woodland is destroyed by fire in one of the Rocky Mountain States, it often happens that

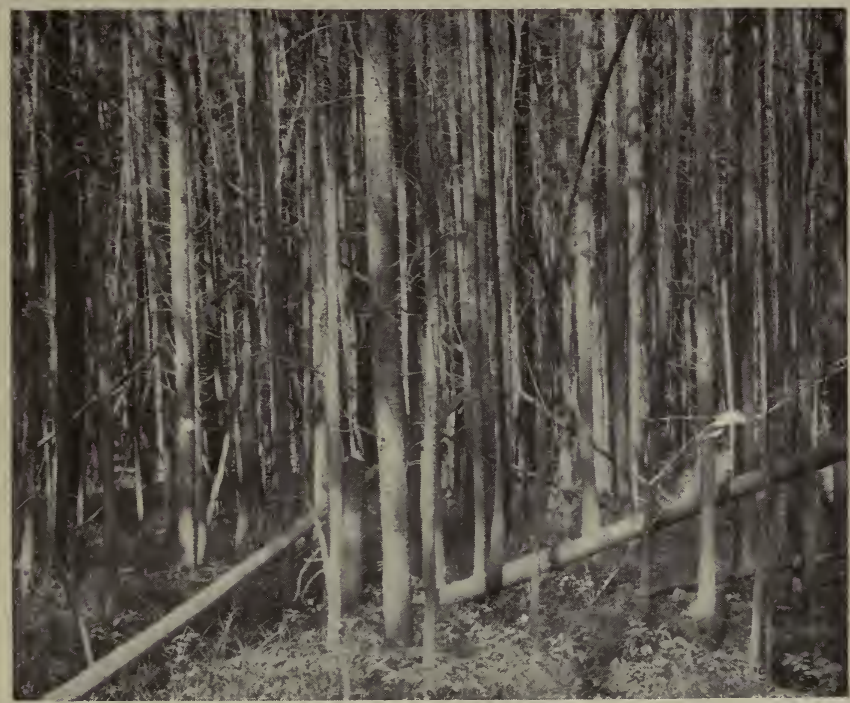

FIG. 12.-Seed forest of lodgepole pine in Idaho.

the seeds of the lodgepole pine are scattered over it by the wind in prodigious numbers. The seeds germinate abundantly, seedlings spring up, and in a very few years a young even-aged forest of lodgepole pine $1116-05-3$ 
covers the ground. As it grows older fires destroy patches of it here and there, and in time every patch is covered again with a younger generation of even age. After many years the forest which sprang up after the first fire has become broken into a number of even-aged patches without uniformity in size or regular gradations in age.

Now let us suppose that this land was taken in hand by the Government when the lodgepole pine first came in, and that the lodgepole reaches its maturity at 80 years. If the Government forest officers had divided such a forest into eighty parts, and then had cut the timber from one part each year, after a time they would have had eighty divisions, each covered with even-aged forest, but differing in age among themselves from 1 to 80 years. Every year one part would reach the age of 80 years and would be cut, and eridently the other seventy-nine parts would always be stocked with trees from 1 to 79 years old.

When the trees on one of the eighty di visions just mentioned become ripe for the ax, provision must be made for a new crop. This would be a very simple matter if the forest on that division could be reproduced naturally in one year, but that is practically impossible. Such rapid reproduction can be got only by planting, which is chiefly useful in the United States for making new forests and restoring injured forests, not for renewing old ones. Reproduction from the seed of the old trees is the only kind we need consider here. In order to bring it about a few ripe trees are first cut down, to prepare a seedhed hy giving light to the soil, and to fit the seed trees to bear 


\section{BEFORE CUTTING}

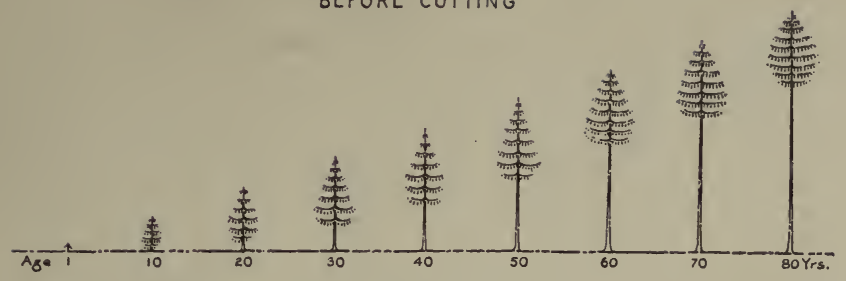

AFTER CUTTING
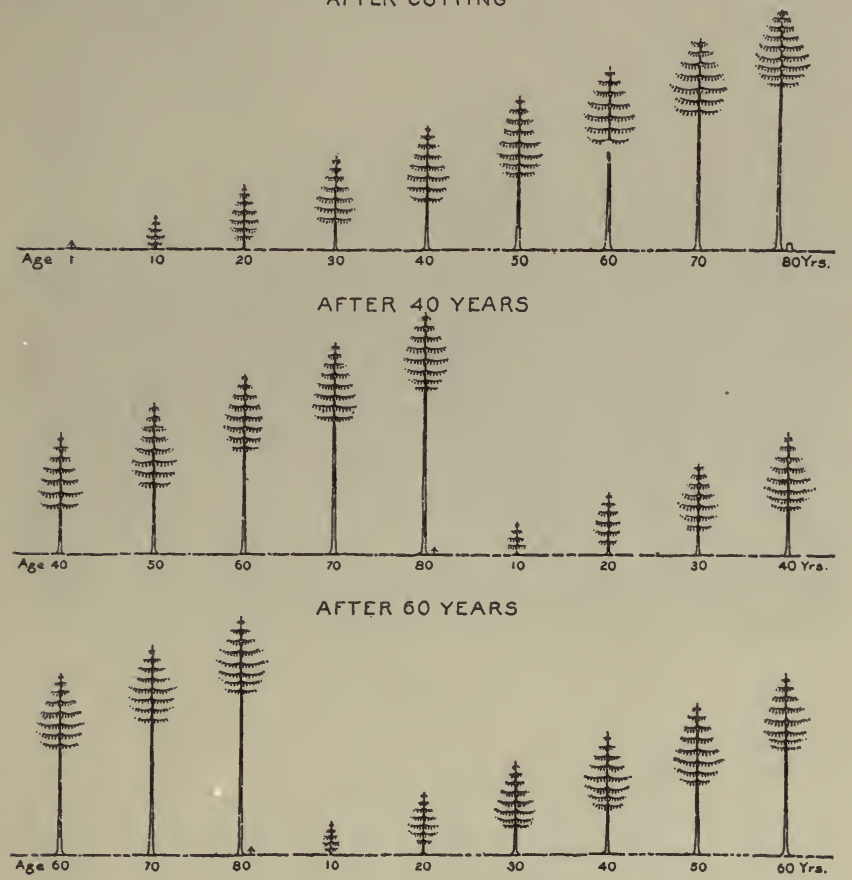

Diagram to Represent the Progress of Cutting in Regular Seed forest.

Each tree represents one even-aged division. Only one division in ten is represented. 

more abundantly by giving the crowns more room. Then, when a good crop of seed is likely to appear, a few more trees are removed to give the future seedlings light enough for healthy growth, but not enough to expose them to danger from frost, drought, or the choking of grass and weeds, for young trees just start-

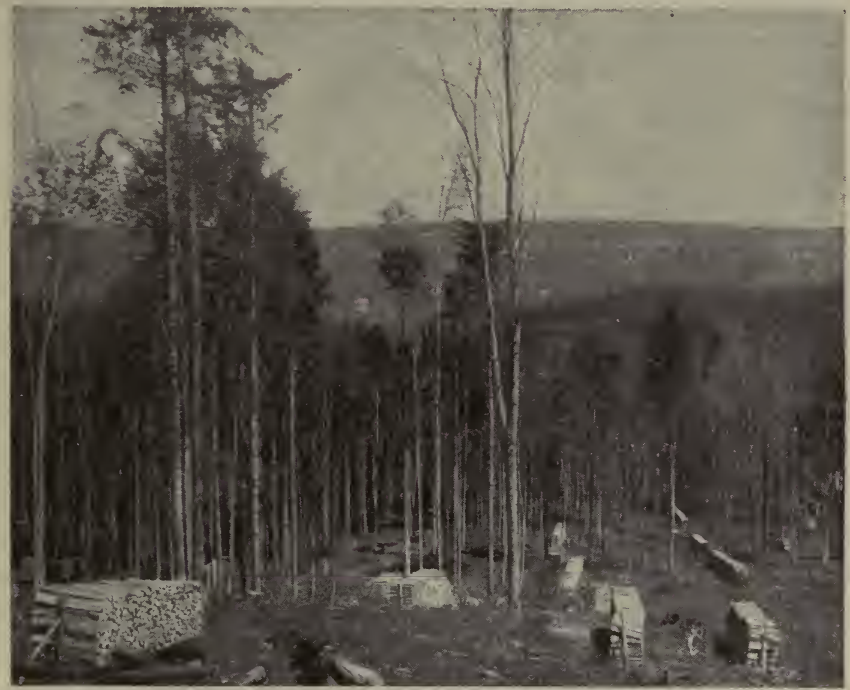

Fig. 13.-Mixed forest in process of gradual reproduction. Sihlwald, Switzerland.

ing in life are very sensitive and easily destroyed. Finally, as the young trees grow taller and stronger, what remains of the old crop is gradually cut away. When it is all gone, usually from ten to twenty years have passed since the reproduction cuttings were begun. 
This is the system of Regular Seed Forest. It is difficult to apply, and unsafe except in experienced hands. It has often been necessary to plant large areas at great expense hecause reproduction cuttings in Reg-

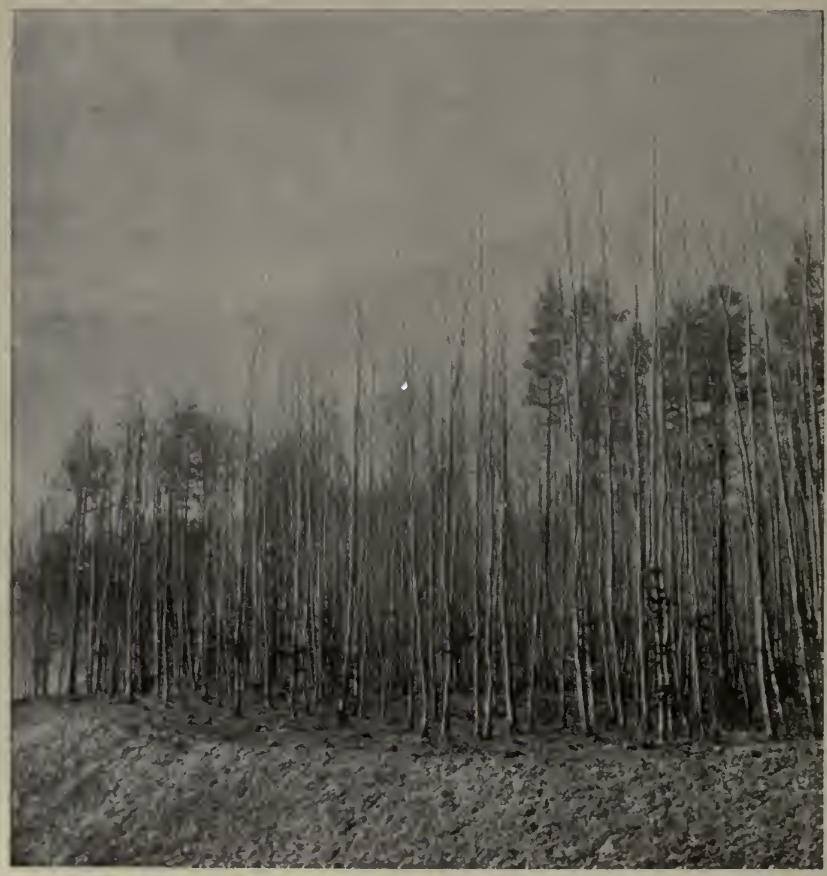

Fig. 14.-Reproduction obtained by process shown in fig. 13. Sihlwald, Switzerland.

ular Seed Forest have failed. The transportation of the timber is frequently expensive, because it must be spread over a number of years. On the other hand, when it is well applied this system produces the 
highest type of forest, full of tall straight trunks clear of branches, and consequently yields a high grade of timber and a large return in money.

\section{TWO-STORIED SEED FOREST.}

After a forest fire in Maine it frequently happens that the first tree to cover the ground is the popple, or quaking aspen. It is a slender, short-lived tree, intolerant of shade, with a light crown. After the popple has grown for some year's, spruce seedlings spring up under the friendly cover, and rapidly follow the popple in height. There grows up in this way a forest composed of an upper and a lower story of growth, in which, as so often happens, the lower story is of more importance.

The system of Two-Storied Seed Forest is useful when a tolerant tree like the spruce is to be grown under the shade of an intolerant tree like the aspen. In countries where forestry is well developed it is usual to plant young trees of tolerant species under older intolerant trees, to make a cover for the soil and to prevent the growth of grass and weeds. Forests which closely resemble two-storied seed forests are common in the United States, but usually as the result of fire or careless cutting. Such are, for example, the forests of pine over oak in the Southeastern United States, and of birch, beech, and maple under white pine in Michigan, Wisconsin, and Minnesota. It often happens, as in the case of the spruce and aspen, that both stories can not live on in good health together, and that the upper one must die or be cut away if the lower is to prosper. 
SELECTION FOREST.

When a stand of aspen dies away from a young crop of spruce, the ground is no longer completely shated,

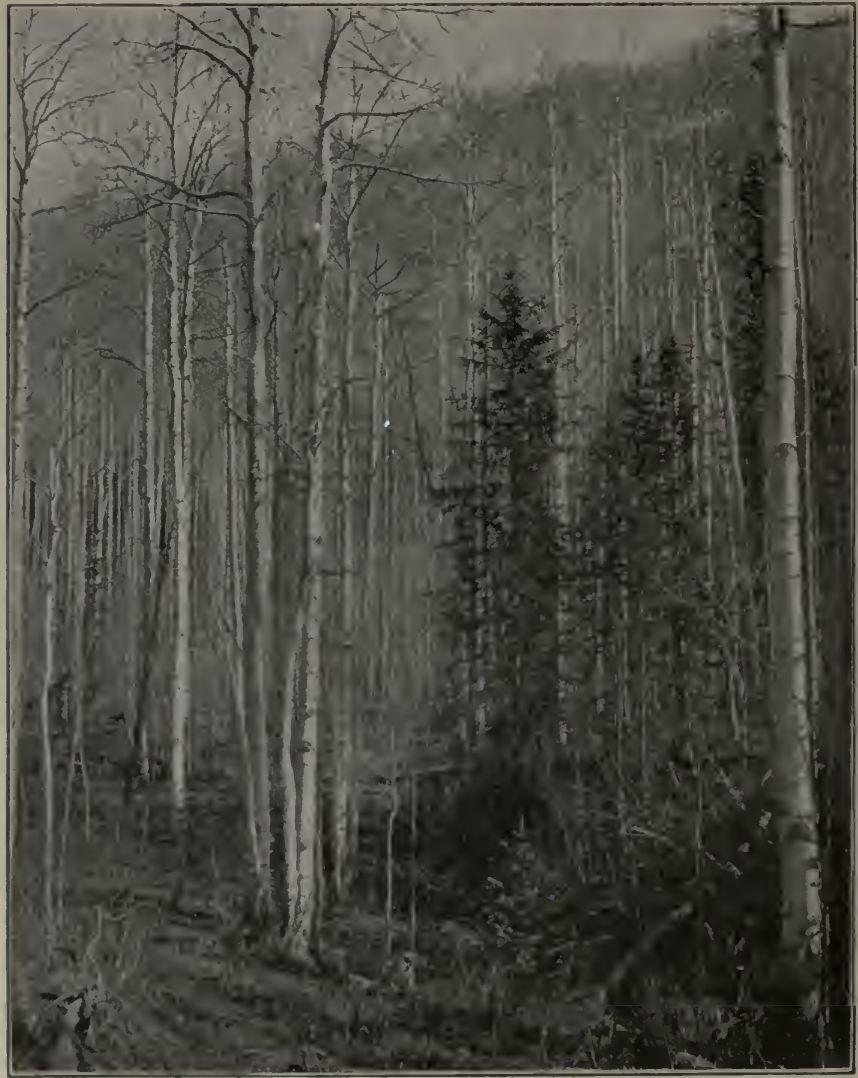

Fir: 15.-Young growth of spruce under older growth of pupple. Coloraclo.

and there is light and room for other kinds of trees to come in. Thus, birch and maple seeds may be blown 


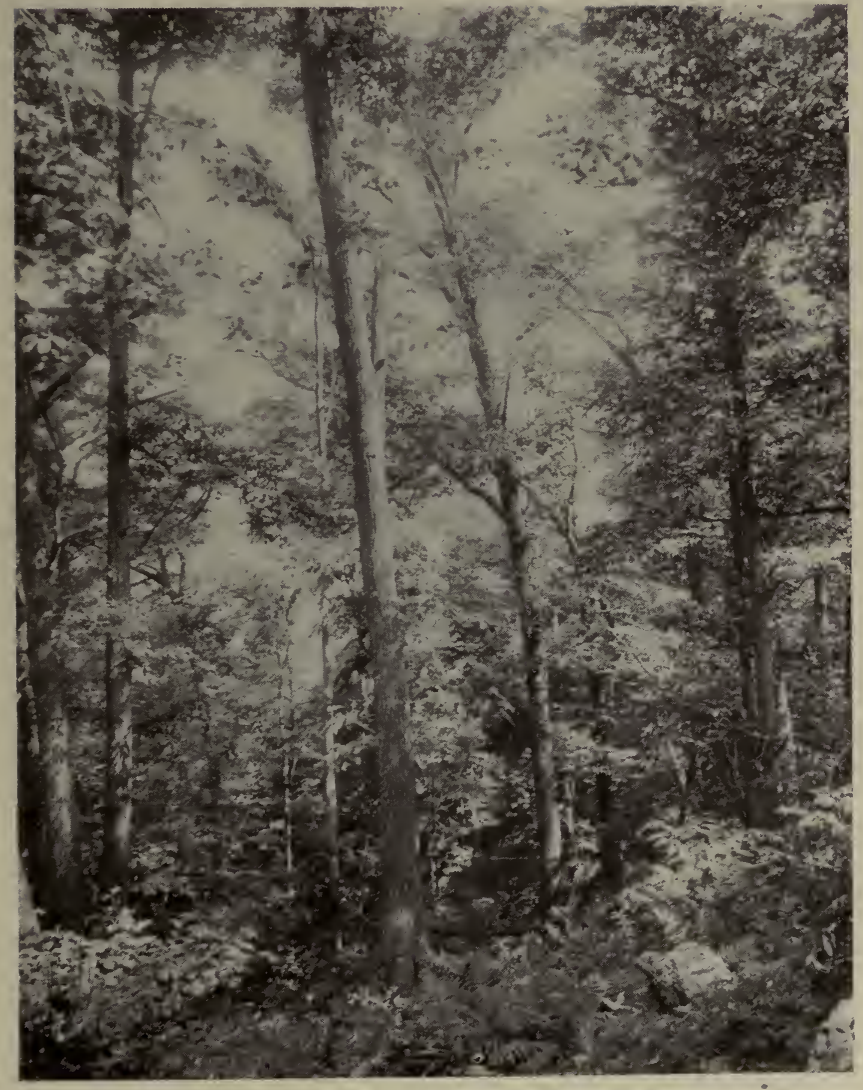

Mixed Selection Forest in the SOUthern Appalachians. 

in by the wind and beechnuts carried and planted by squirrels, and eventually the pure stand of spruce is changed into a mixed forest of various ages. As the trees grow older, some of the spruce may be destroyed by beetles or thrown by the wind, and some of the broadleaf trees may die from fungous disease. Into the openings made by the death of older members of

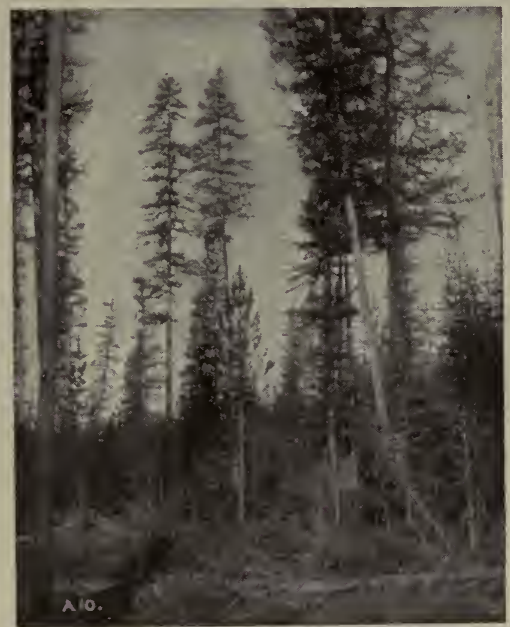

Frg. 16.-Lodgepole pine and western lareh in selection forest. Northern Idaho.

the forest fall the seeds from which younger members spring. So little by little the forest loses its even-aged character and there comes into existence what is called a Natural or Selection Forest, in which trees of all ages are everywhere closely mixed together. Most virgin forests are selection forests. 
The silvicultural system called Pure Selection is applied to forests of this kind. It is used chiefly for protection forests in places where it is desirable to keep the cover always unbroken; elsewhere it is out

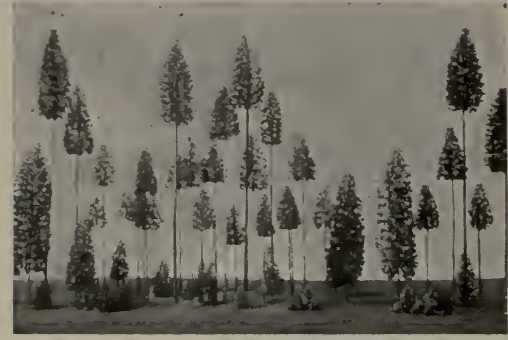

FIG.17.-Mimic pure selection forest, showing the mixture of ages. of place. Under this system the annual increase of the forest must be found before the yield can be determined. (see p. 15.) Then the fully mature trees are cut in every part of the forest every year. 'The cost of logging is high, for where single trees are taken here and there, roads or other means of transport must be very numerous and costly in proportion to the amount of the cut.

\section{LOCAI.IZEI) SELECTION.}

Logging under the system just mentioned is so expensive as to prevent its application in the United States, except for woods like cherry and black walnut, which have a special and unusual value. But if, instead of taking the yield from every part of a selection forest, a comparatively small area is cut over each year, the cost of logging may be very greatly reduced. Such a method is admirably adapted to certain forest regions in the United States, as, for example, to the Adirondack Mountains of New York, where the forest is composed about equally of coniferous and broadleaf trees. 
The conifers are the more valuable, and among them the principal lumber tree is the spruce.

The Bureau of Forestry has found by many careful measurements that if all spruce trees 12 inches and over in diameter are eut from certain portions of the Adirondack forest, the younger spruce will grow up and replace the original stand of timber in about twenty years. But this will not happen unless the

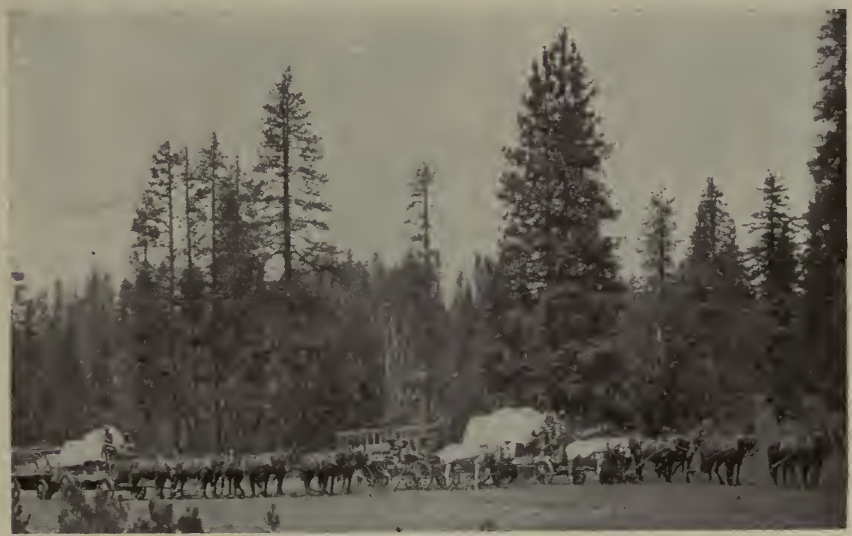

FIG. 18.-Natural forest resembling Localized Selection. Southern Oregon.

rules for cutting are faithfully observed, nor will it happen more than once unless enough old trees are left standing for seed. Such a forest may then be divided into twenty parts, and the merchantable timber about 12 inches in diameter may safely be cut from one division every year. By the time the last of the twenty divisions has been cut over, the first will have upon it a stand of mature spruce equal in quantity to that of 
twenty years before. The yield of the whole forest in spruce for a single year may be cut each year from one-twentieth of the whole area. If all the divisions were cut over five times in the life of a mature tree, then one-fifth of the standing timber would be taken

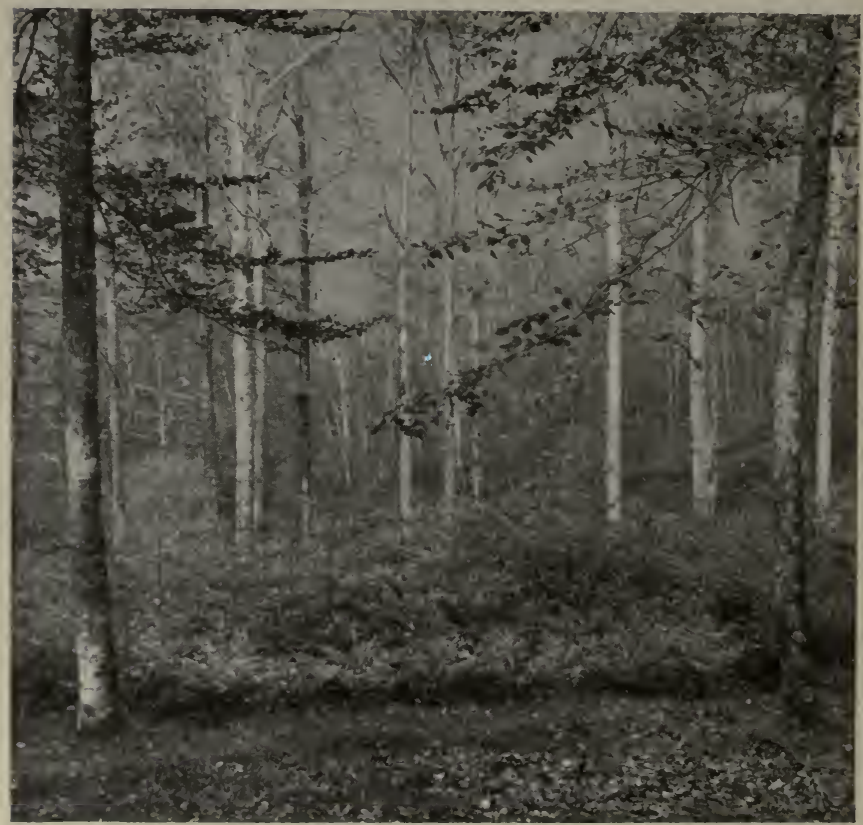

FIG. 19.-Group of spruce under beech. Germany.

from each division at each cutting. Thus, if it took one hundred years for a tree to become ripe for the ax, the cutting (at intervals of twenty years) would return five times during the life of the tree, at its twentieth, fortieth, sixtieth, eightieth, and one hundredth years. 
This is the system of Localized Selection. It is simple and easy to apply, and even if mistakes occur they are not apt to have dangerous consequences. It is very elastic and has many forms, and it is well adapted to many different kinds of forest. Logging is cheap, because the area cut over in any one year is small, and the reproduction is provided for by natural seeding in the openings of the forest.

THE GROUP SYSTEM.

It often happens that all the trees of a small group in the forest are killed by fire or insects at about the same time. In the opening thus made the ground is quickly covered with young growth, which extends back under the old trees as far as the light will permit. The seedlings are usually tallest, strongest, and

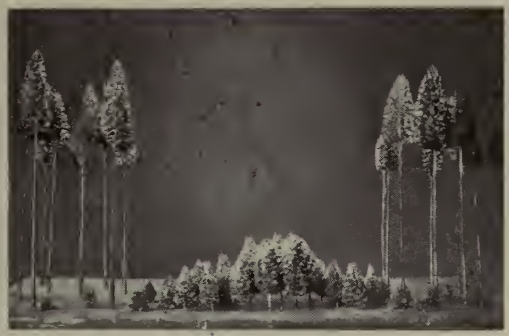

FIG. 20.-Mimic orest, showing distribution of young growth under the Group System.

most numerous directly under the middle of the opening, and gradually decrease at the sides. If the wind should throw some trees at the edges of such an opening, the young growth would gradually extend, and if the same thing should continue to happen, in the end all the old trees would have disappeared and their places would have been taken by young growth. The Group System is an imitation of this process. 
Under the Group System openings are made here and there in the forest by cutting away ripe trees. As the reproduction proceeds, the old trees about the openings are gradually cut away, and the groups of young growth, spreading from the original openings like drops of oil on water, finally meet.

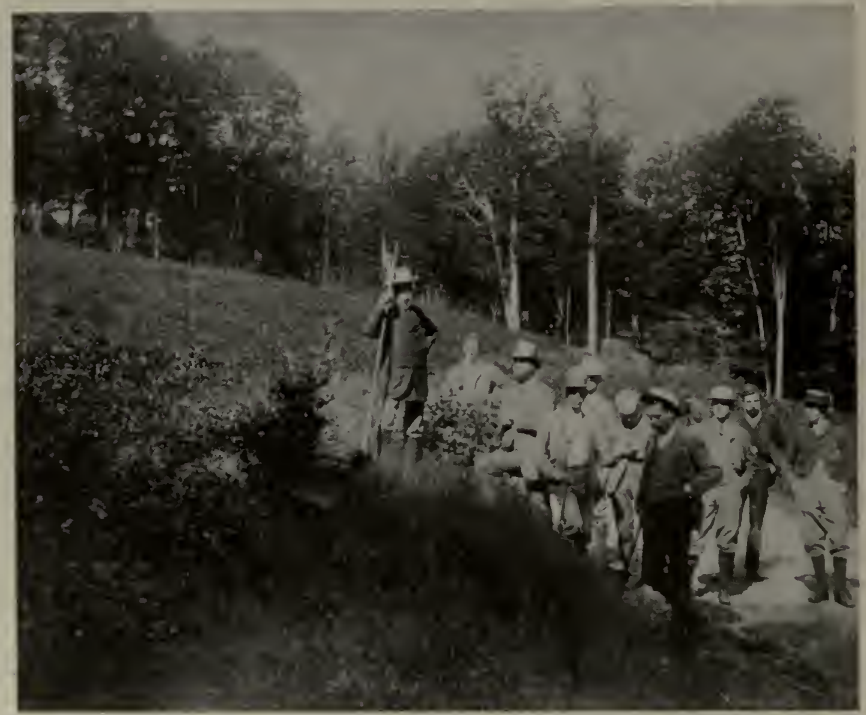

FIG. 21.-Large group of young planted oak. Sir Dietrich Brandis and the English forest students of 1890 . Germany.

This is one of the simplest and most useful of all the systems, and when the openings are made small at first no other is so safe. It is especially adapted to small pieces of forest, such as woodlots, because it is simple, and because it assures the safety of the forest even with very little skill or care on the part of the owner. 
In nearly every wooded region of the United States a tornado occasionally destroys the trees in a long and narrow belt through the forest. Fire often follows and clears the strip by burning up the fallen timber. Seeds then fall in the opening, carried from the trees on either side, the seeds germinate and grow, and the reproduction of the forest takes place.

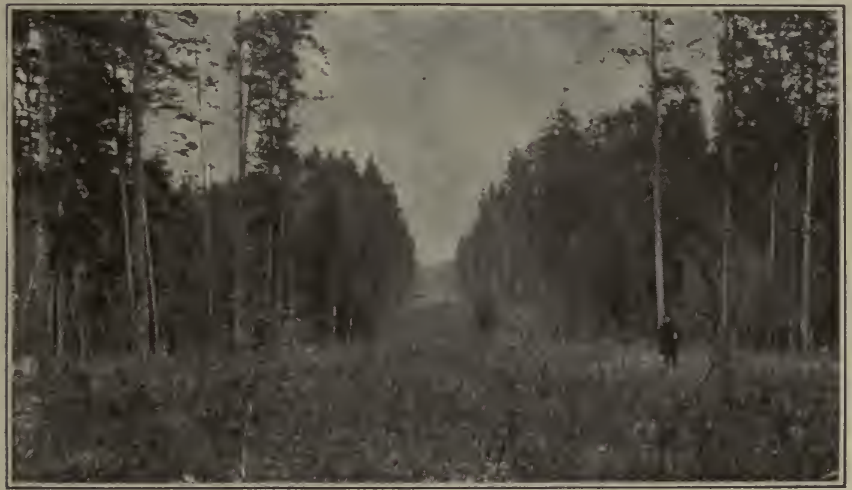

FIG. 22.-Spruce managed under the Strip System. Southern Russia.

When the ax takes the place of the tornado and the timber is logged instead of being burned, the Strip System is applied. Reproduction follows from trees on either side, as before. The Strip System consists in cutting long narrow openings in the mature timber instead of the circular openings of the Group System, to which it is similar in many ways. It is simple and effective when natural reproduction is good, and well suited for extensive operations in places where careful $1116-05-4$ 
work is impossible. The strips are usually not over 100 yards in width. Where the soil is dry, they are run east and west to protect the young growth against the sun, and are comparatively narrow. If there is serious danger of windfall, they lie at right angles to the direction of the wind.

These are the more important of the silvicultural systems. They have many modifications, and indeed each forest may require a special form of its own, which must be devised or adapted for it by the forester. But whatever the form, the object is always to use the forest and provide for its future at the same time.

\section{IMPROVEMENT CUTTINGS.}

Very many forests in the United States, and especially many woodlots, are in poor condition and unfit for the immediate application of any silvicultural system. They need to be put in order, and for that purpose Improvement Cuttings are usually required. In the end these cuttings should remove all trees which the forest is better without, but they should be made gradually, so as not to open the cover too much and expose the soil to the wind and the smin. In general, it is unwise to cut more than 25 per cent of the poles and older trees in a dense mature forest, or to cut oftener on the same ground than once in five years. Improvement Cuttings of course should never fall on trees which are to form the future crop, but they should remove spreading older trees over promising young growth; poor trees which are crowding more valuable ones; unsound trees whose places will be taken by 



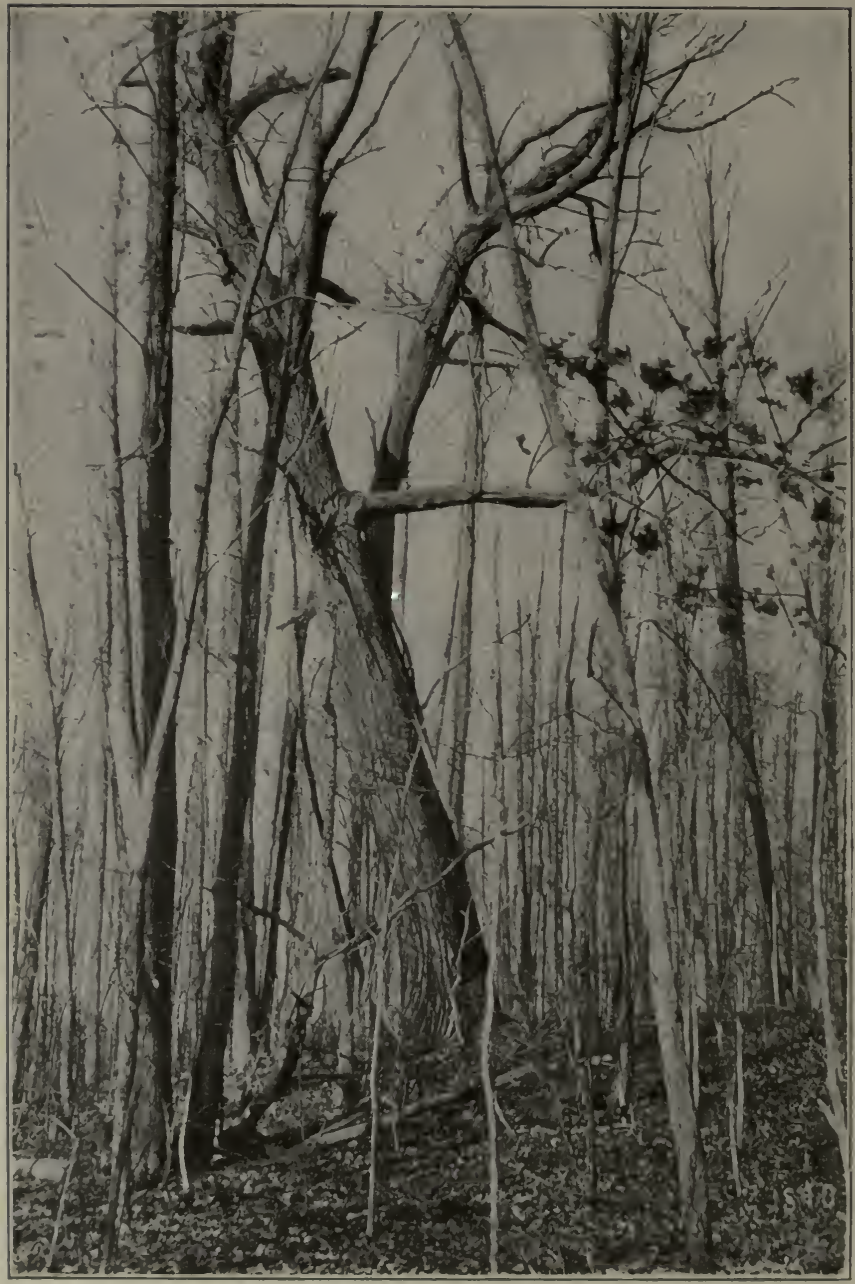

A Mixed Forest in Need of an improvement Cutting.

The crooked old chestnut in particular should be removed 


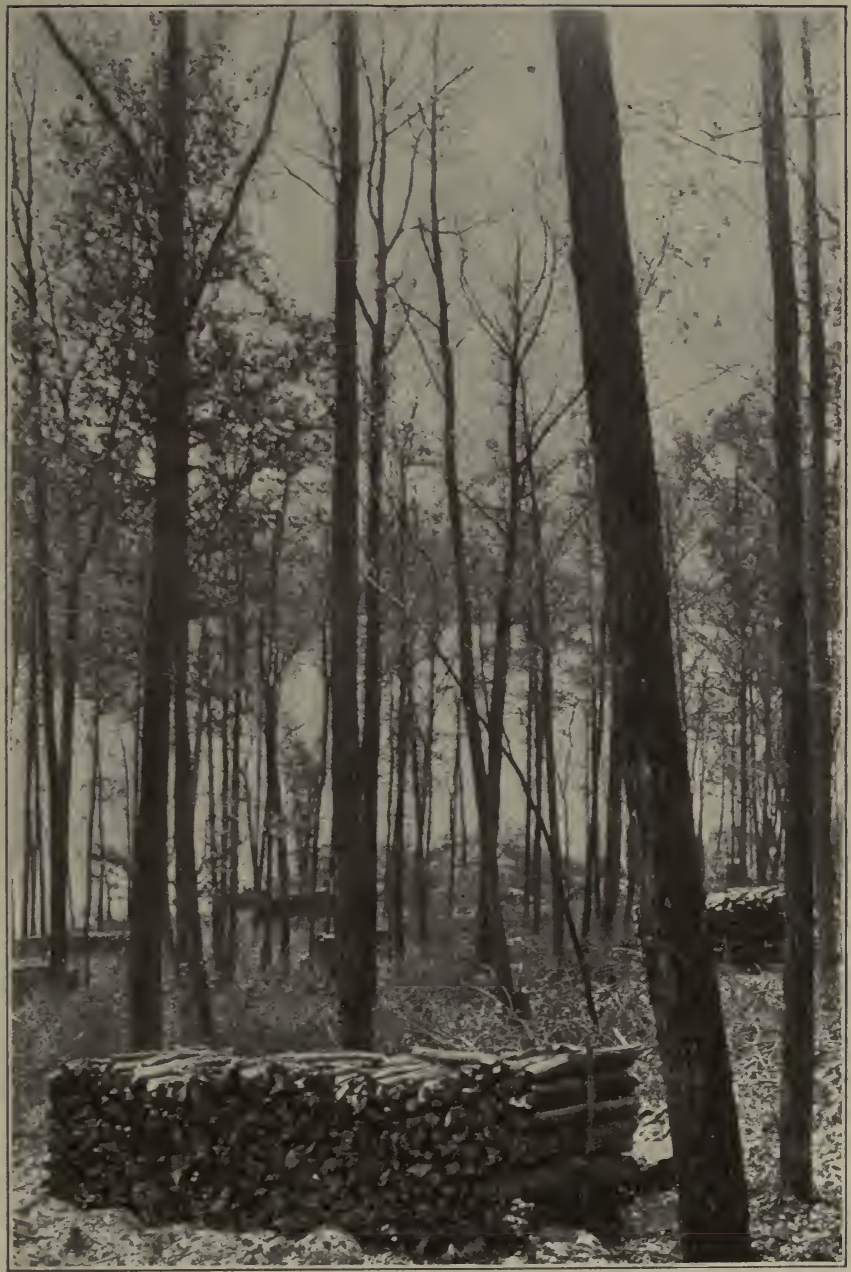

A Mixed Forest after an Improvement Cutting. 

others of greater value, or which are themselves becoming less valuable from year to year; and seed trees of undesirable species likely to reproduce themselves, if reproduction of more useful kind is well assured. The great majority of woodlots need such cutting, and when they do, whatever wood is taken from them should be cut in this way.

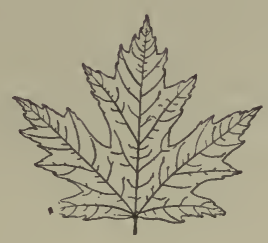




\section{CHAP'TER II.}

\section{WORK IN THE WOODS.}

The products of the forest are ainong the things which cirilized men can not do without. Wood is needed for building, for fuel, for paper pulp. and for unnumbered other uses, and trees must be cut down to supply it. It would be both useless and mistaken to try to stop the cutting of timber, for it could not cease without great injury, not to the lumbermen only, but to all the people of the nation. The question is not of saving the trees, for every tree must inevitably die, but of saving the forest by conservative ways of cutting the trees. If the forest is to be preserved, the timber crop now ripe must be gathered in such a way as to make sure of other crops hereafter.

In general, it is true that the present methods of lumbering are unnecessarily destructive and wasteful. This is not because lumbermen are more greedy of gain or less careful of public interests than other business men, for they are not. It happens partly because in this country, compared with France and Germany and other densely populated regions, there is so much timber in proportion to the population that it does not pay the lumberman to take anything more than the better parts of the trees he fells. The lumberman can not do his work unless he does it at a profit, and he 
must do it, for lumber is indispensable. Consequently, although much of the waste in lumbering is not only unnecessary, but actually costly to the lumberman, for the present it is impossible to aroid waste altogether. It will be easier to do so when the methods and advantages of conservative lumbering, which is forestry, are better known to the American lumbermen, and are therefore in more general use. Although rough conservative methods have often been practiced in the past, the success of the lumbermen who made the trial was generally but partial, because their knowledge of the forest was partial also. They were often deceived by underestimates of the capacity for tree growth of the lands they were handling, because accurate measurements were wanting, and they seldom made full use of the reproductive power of the forest. More recent attempts, based on better knowledge, have been successful in almost every case.

Lumbermen in America are second to none in skill and ingenuity, in the perfection of their tools, and in the effectiveness of the methods they have devised. The nations of Europe, although they have given far more attention to forestry than we, are rery much behind the United States in these respects. So it is not surprising that Americans have been slow to change their methods, especially when methods and lumbermen alike have often been attacked as wrongly and intemperately as the foreign methods have been praised and recommended. German methods would be as much out of place in America as American methods in Germany. What American foresters should do and are doing is to combine the general principles of 
forestry, which are true all the world over, with American methods of lumbering. The product will be a system of forestry especially adapted to the United States. The foundations of such a system are already laid.

\section{CONSERVATIVF: LUMBERING.}

Something was said in the last chapter about the systematic methods of conservative lumbering. With the

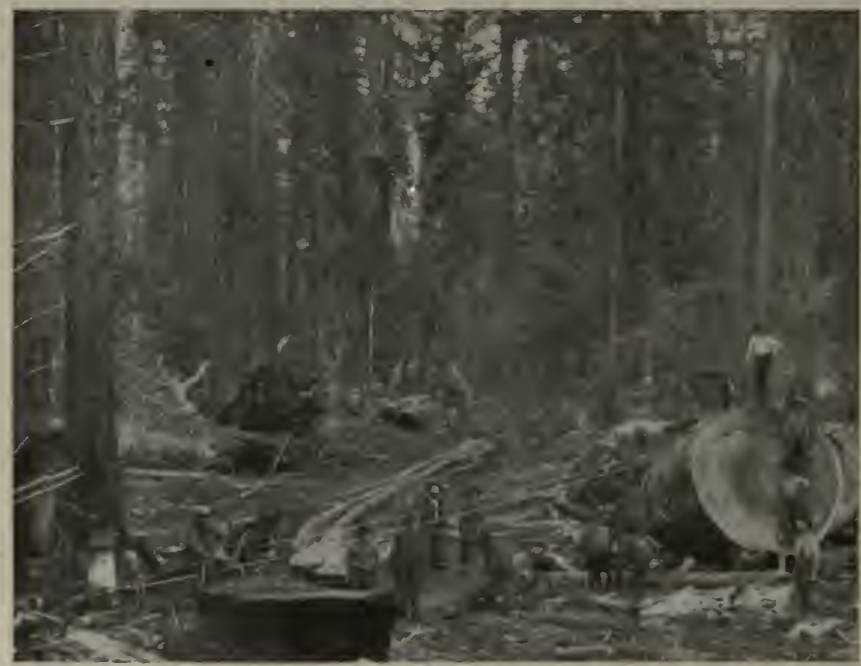

Fig. 23.-Logging of great mechanical perfection among the Big Trees of California.

gradual understanding and application of these methods by American lumbermen, already well begun, and with the work in the woods rightly carried out, there is but one reason why the great majority of the forests now standing in the United States should not in the end 
be lumbered steadily and systematically, or why they should fail to yield a steadily increasing return. That reason is the rapid destruction of the forests themselves. There is grave danger that the best of our forests will all be gone before their protection and perpetuation by wise use can be begun. The spread of a working knowledge of practical forestry is likely to be too slow.

CONSERYATIVE LUMBERING AND ORDINARY LUMBERING.

Conservative lumbering is distinguished from ordinary lumbering in three ways:

First. The forest is treated as a working capital whose purpose is to produce successive crops.

Second. With that purpose in view, a working plan is prepared and followed in harvesting the forest crop.

Third. The work in the woods is carried on in such a way as to leave the standing trees and the young growth as nearly unharmed by the lumbering as possible.

A forest working plan is intended to give all the information needed to decide upon and carry out the best business policy in handling and perpetuating a forest. It gives this information in the form of a written statement, which covers some or all of the following topics. It shows the present stand and condition of the forest, and gives rules for the selection and marking of trees to cut, for making the reproduction sure, and for the protection of young and old standing trees during the logging. The working plan also predicts the future yield of the forest, basing its prediction on careful measurements which show how many standing 
trees of different diameters will be left per acre after the first cutting, and how fast these young trees grow. Finally, it estimates the future return in money, taking into account the taxes, interest, and other expenses on one side, and the future crop on the other. In order to make this estimate

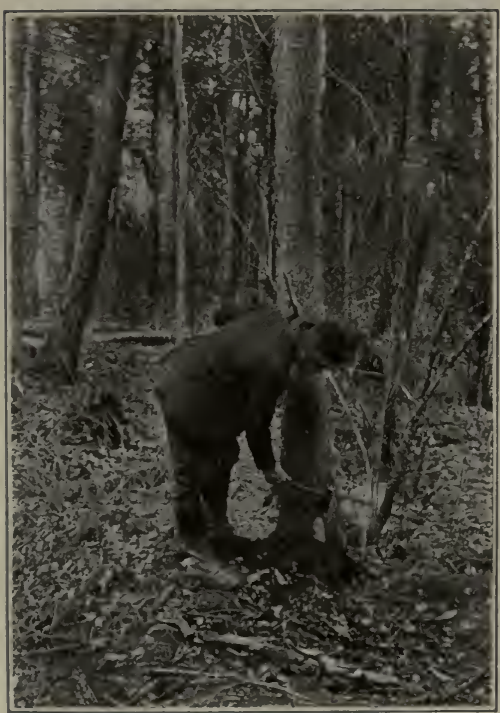

Fig. 24.-Government forester marking trees to cut. Adirondack Mountains, N. Y. entirely safe, it is usually based on the present price of stumpage, although its future value will certainly be much higher.

FELLING THE TREES.

The difference between the practical work under ordinary lumbering and under conservative lumbering is chiefly in the selection of the trees to cut, in felling them, and in the first part of their journey from the stump to the mill. Under a working plan the trees to cut are chosen in such a way that when they are gone the forest will suffer but little from their absence, because their places will he taken by others as quickly as possible. Usually the trees selected are first stamped with a marking hatchet to prevent mistakes, and then the next step is to cut them down. 
The amount of harm done to the forest by the cutting depends considerably upon the season of the year when the work in the woods is carried on. Less damage results to the young growth and the trees left standing if the lumbering is done after the growing season is orer than if it goes on in the spring and summer, while the bark is loose and the leaves and twigs are tender.

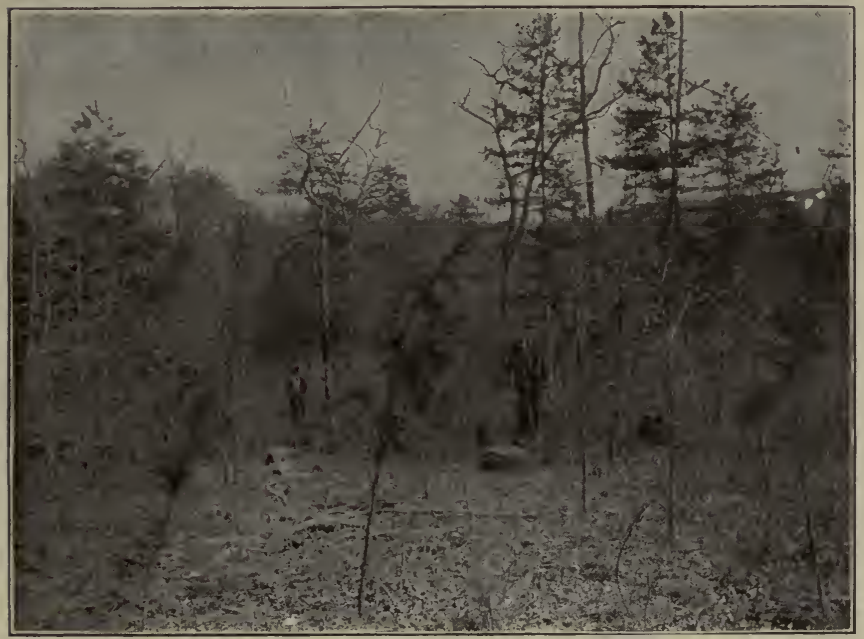

FIG. 25.-Low stumps in logging.

A tree may be felled either with the ax or with the saw. In either case the first thing to consider is the height above the ground at which the cut is to be made. High stumps needlessly waste the best timber in a sound tree. Low stumps are slightly more difficult to cut, and therefore a little more expensive, but the additional cost is more than balanced by the gain. 
The measurements made by the Bureau of Forestry have shown that the loss froin cutting high stumps on a tract of 100.000 acres in the Adirondacks, yielding on an average 15 standards per acre, would be 30,000 standards, or at a stumpage value of 50 cents per standard, would be $\$ 15,000$.

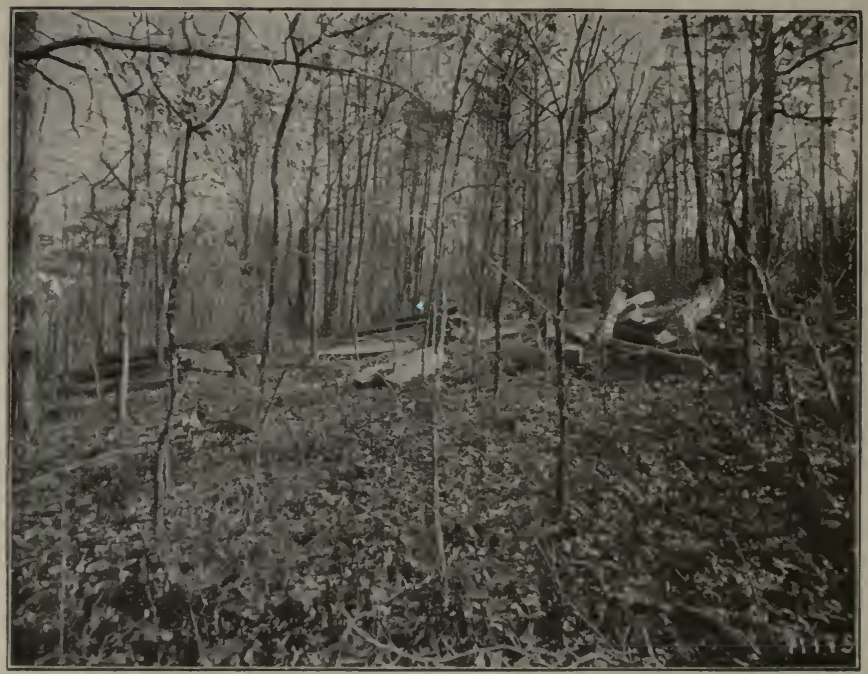

FIG. 26.-Protection of young growth in logging. Biltmore, N. C.

The second thing to consider in felling a tree is how to get it down without breaking or splitting the trunk. On rocky, uneven ground this is often a hard thing to do. but unlessit can be accomplished the tree would, as a rule, better be left untouched.

Most important of all for the perpetuation of the forest, each tree must be thrown where it will not unnecessarily injure other trees or crush in its fall the young seedlings on which the future of the forest 
ar 


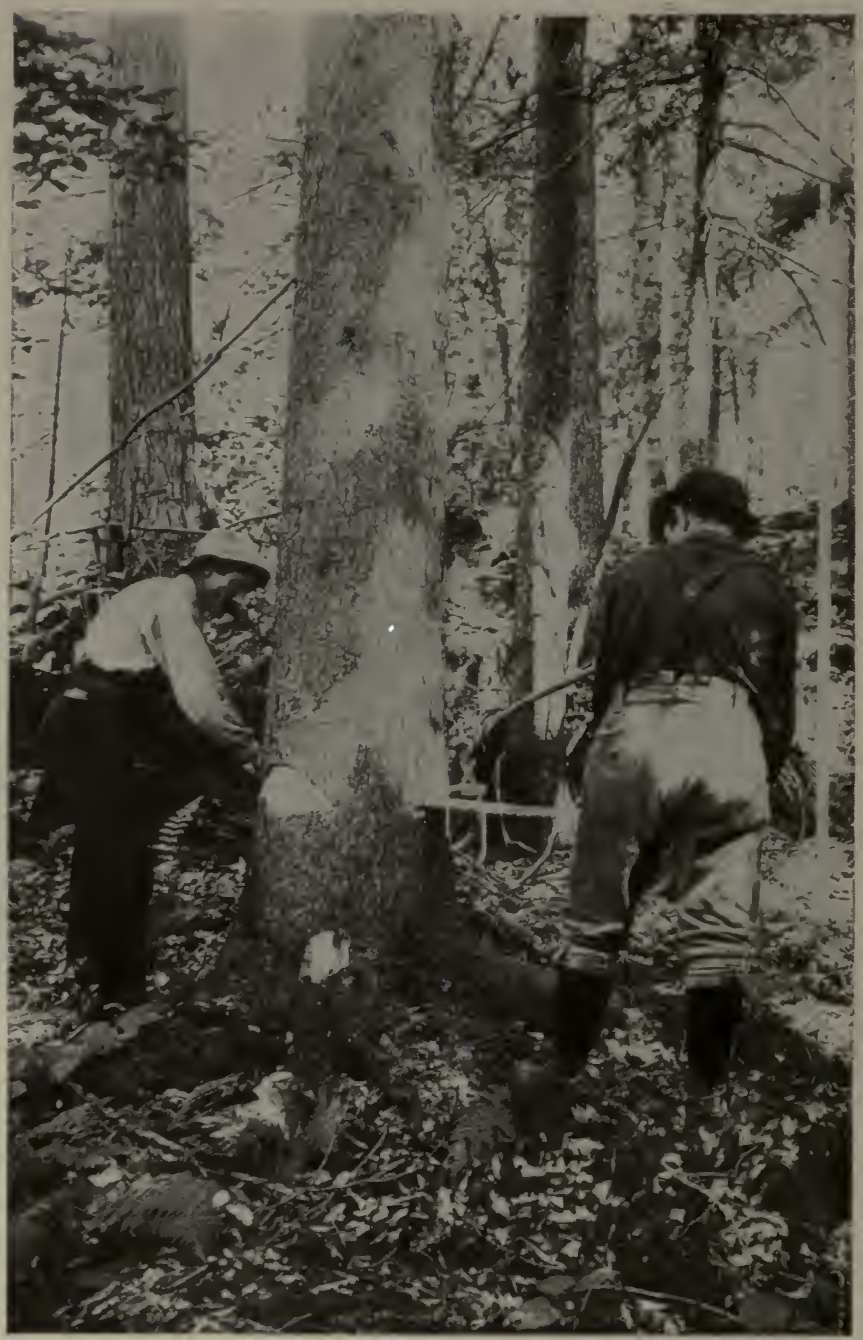

Conbervative Lumbering in the Adirondack Mountains, New York.

Note the height of the stump. 


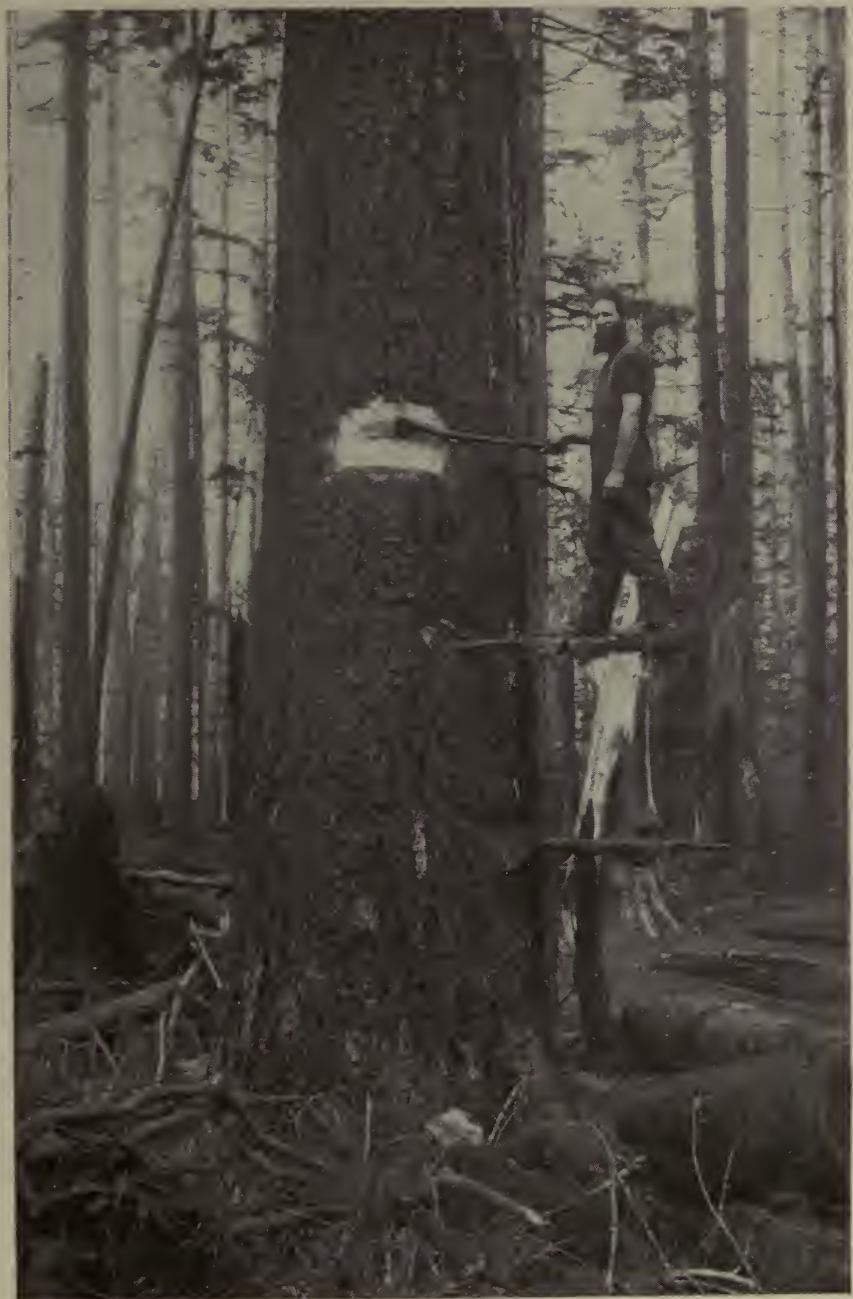

Wasteful Lumbering on the Pacific Slope.

Note the height of the stump. 
depends. It happens very commonly in ordinary lumbering that vigorous, sound young trees are split and ruined in great numbers by old trees falling upon them, when it would be perfectly easy, and almost or quite as convenient, to throw the latter where they would do little or no har'm.

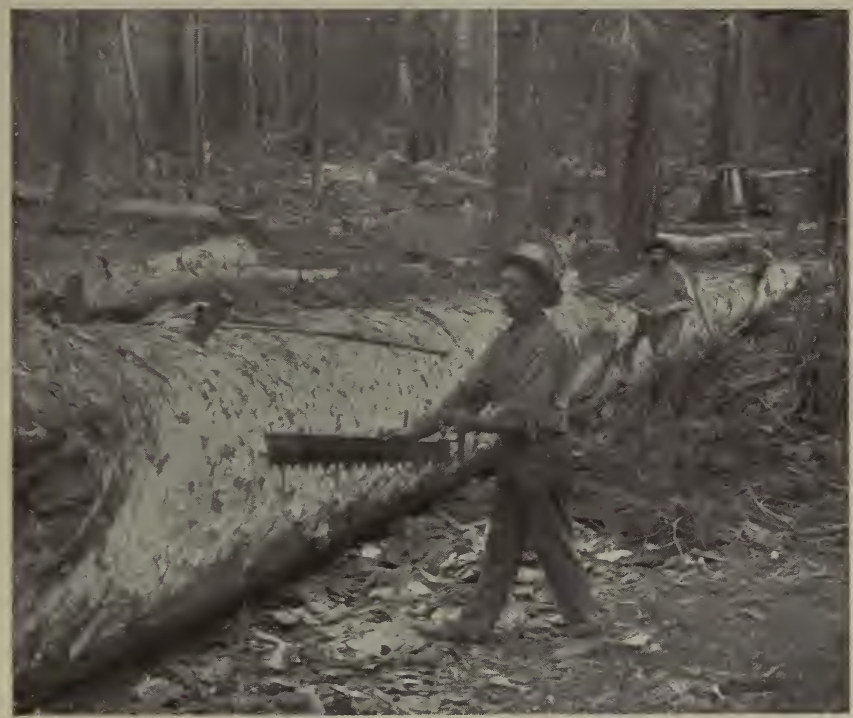

FIG. 27.-Sawing fir into logs. Washington.

Finally, it must cost as little as possible to fell each tree, for to be successful conservative lumbering must pay.

SWAMPING AND SAWING.

When the trees are down, their lower branches are chopped off and the trunks are sawed into logs. In falling, a tree is very apt to bend and hold down 
beneath its trunk and branches many younger trees,

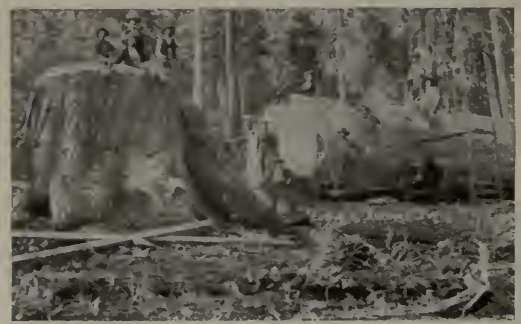

FIG. 28.-Sawing up a Big Tree. California. which will spring up straight again if the $y$ are quickly released. but which otherwise will be killed or permanently hurt. Therefore it is very important to work i1p loth the trunk and the top of each tree as soon as it is eut down, and so prevent it from

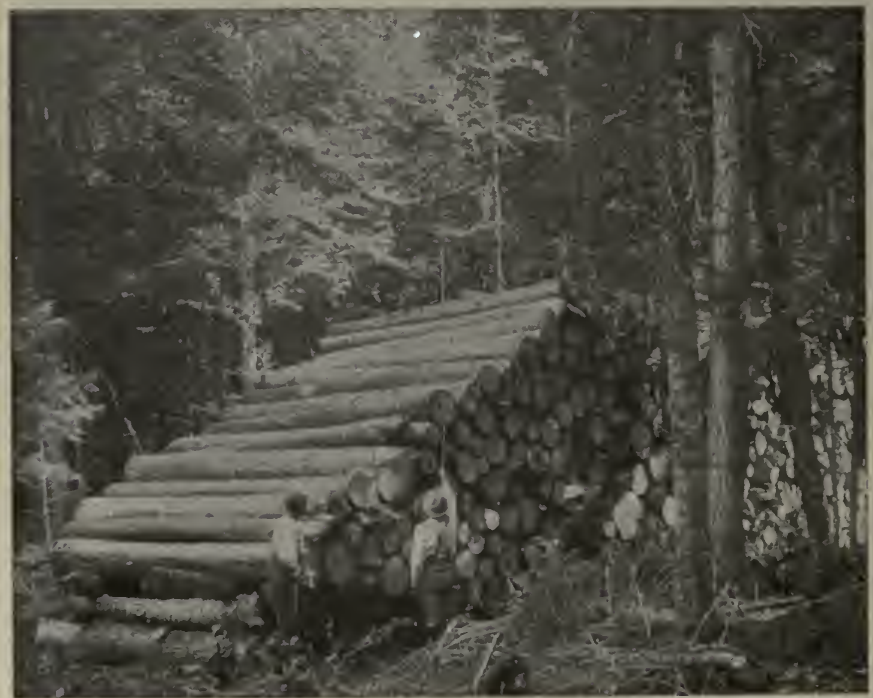

Fig. 29.-Spruce rollway. Adirondack Mountains, New York.

destroying the young trees which should take its place. Fixcept when they are to be burned, even the branches 
of tops which can not be used should ordinarily be cut away enough to let the tops sink close to the ground, where they will rot as speedily as possible. Dry crowns propped clear of the ground by their branches rot slowly, burn fiercely, and are very dangerous in case of fire. (See Pl. I.)

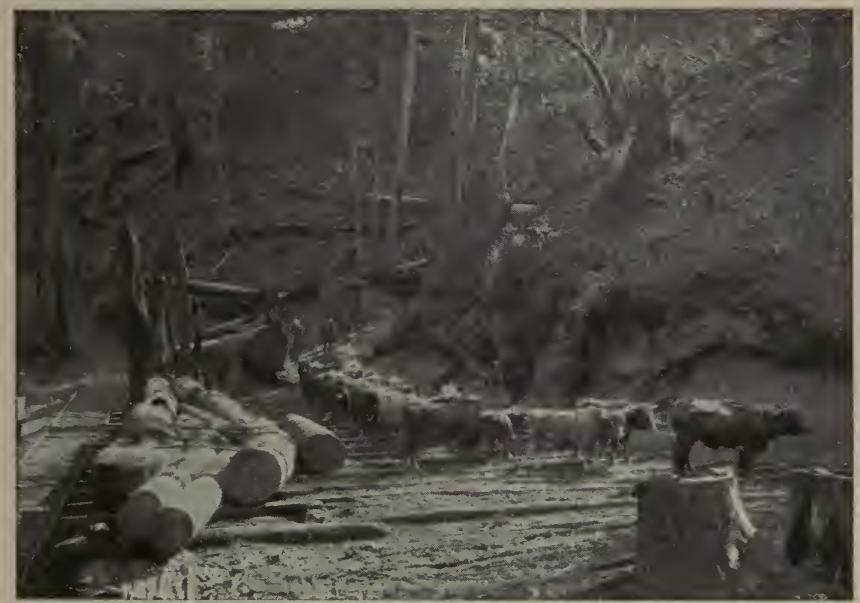

FIG. 30.-Skidding with oxen. Washington.

SKIDDING.

When the trunks have been sawed into logs, the latter are dragged away by horses, mules, or oxen, or in some cases by a long wire rope which is wound on the drum of a donkey engine. This is called "skidding the logs." In this way they are collected in piles called "rollways," or assembled in "yards," or otherwise made ready for the next step in their progress to the mill. 
Care is needed in skidding not to rub or tear the bark from valuable standing trees, or to break the young growth down, for much harm is quickly done in this way. Promising young trees are often eut because it is easier to use them for corduroy or skids, or for other purposes in the logging than to take others less straight

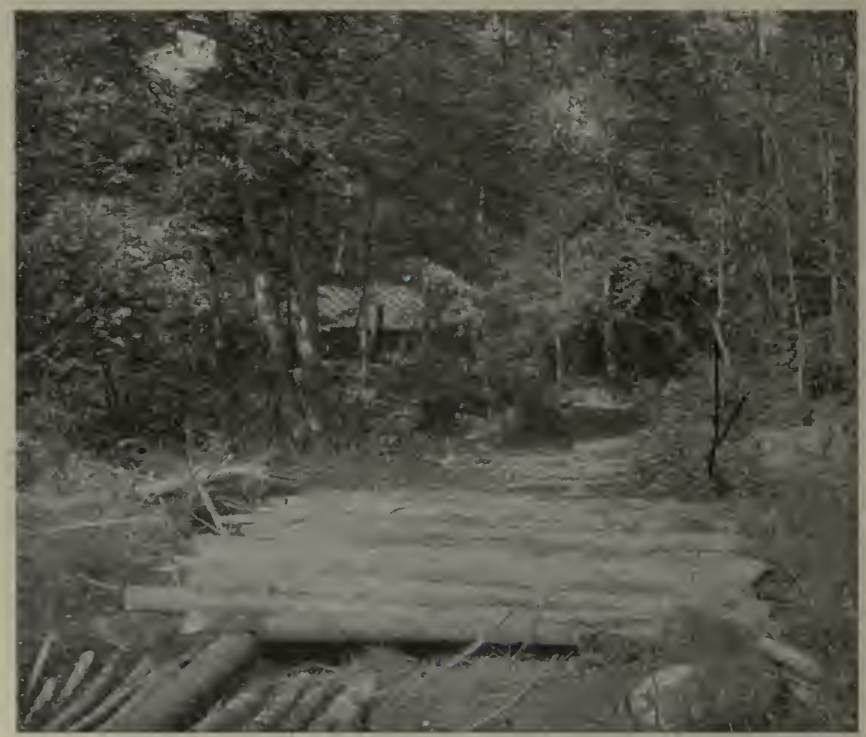

Fig. 31.-Destructive use of young spruce for road building. Adirondack Mountains, New York.

or less conveniently at hand, or because they are somewhat in the way, or even from habit, when it would really be easier to let them alone. A very little care in preserving young growth makes an astonishing difference in the future value of a forest. 


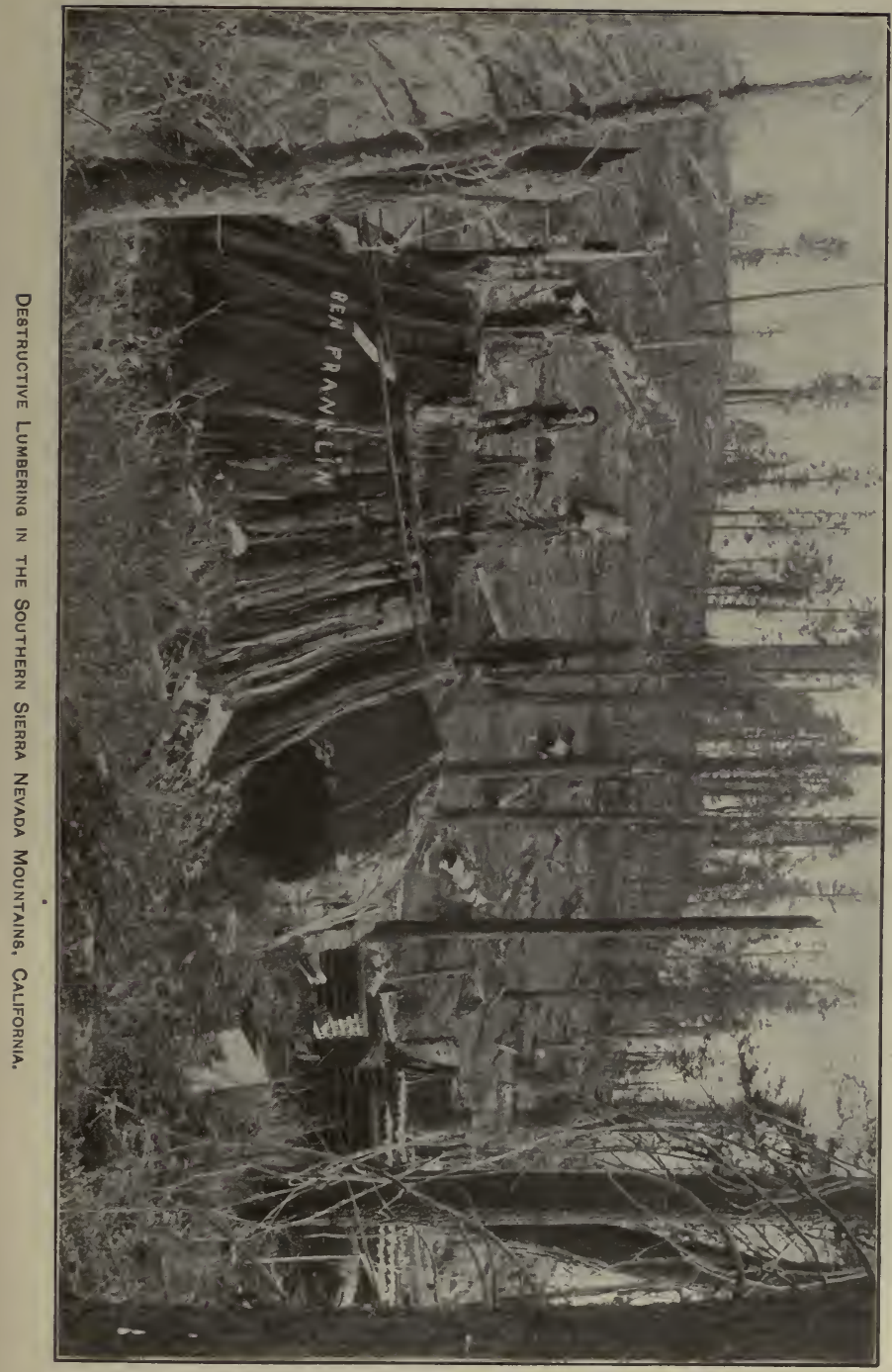




$$
\bullet
$$$$
=
$$ 


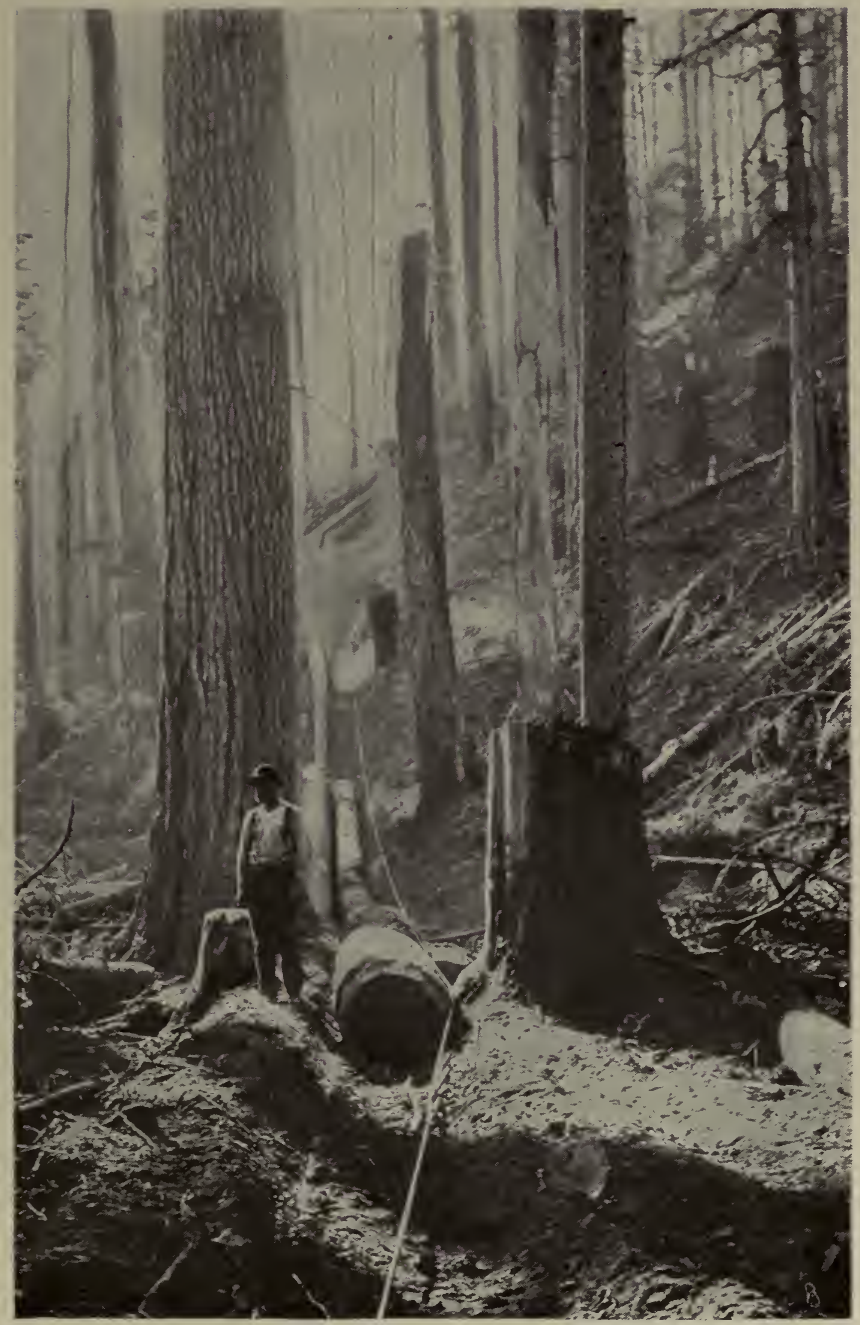

WIRE-ROPE SKIDDING. WASHINGTON. 
TRANSPORTATION

After the skidding, the logs may be transported to the sawmill in many different ways. Sometimes they are loaded on sleds and drawn over carefully made ice roads to a logging railroad or to the bank of a stream. When the stream is not swift or deep enough to carry the logs of itself. splash dams are built, in which great quantities of water are held back for a time. (See

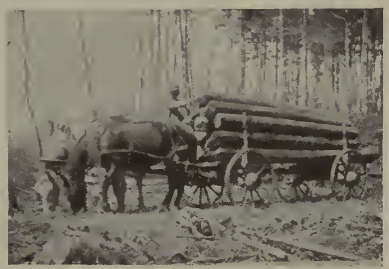

FIG. 32,-Logging white cedar by team. New Jersey.

Pl. XV.) When such a dam is opened the water is set free, and great numbers of logs may be driven far down

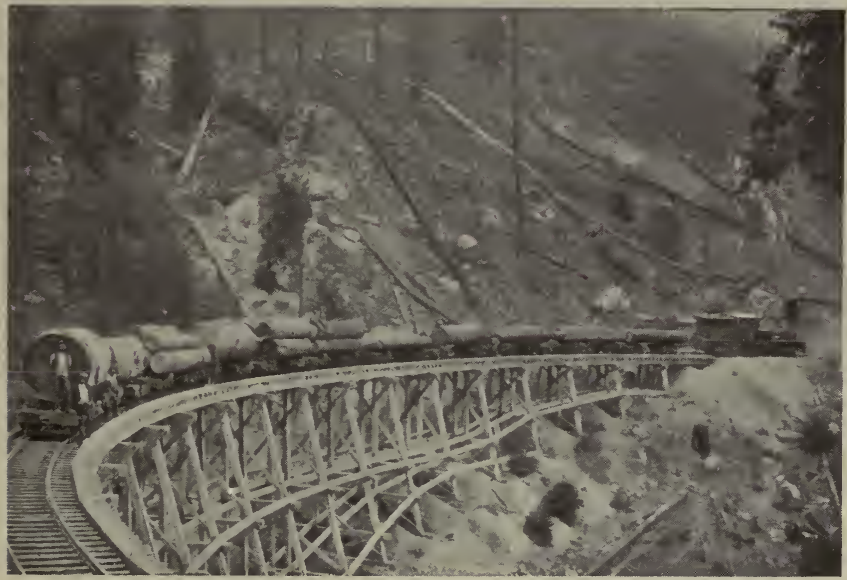

Fig. 33.-Logging by rail. Sierra Nevada Mountains, California.

the stream by the sudden flood. In larger streams the logs are sometimes made into rafts, or they may be 
driven singly down the river. The log drivers who do this work learn to balance themselves on the floating, rolling logs, and walk on them almost as easily as on the solid ground. Sometimes locomotives drag the logs behind them orer the ties. or they are hauled on cars which run over poles cut in the woods instead of

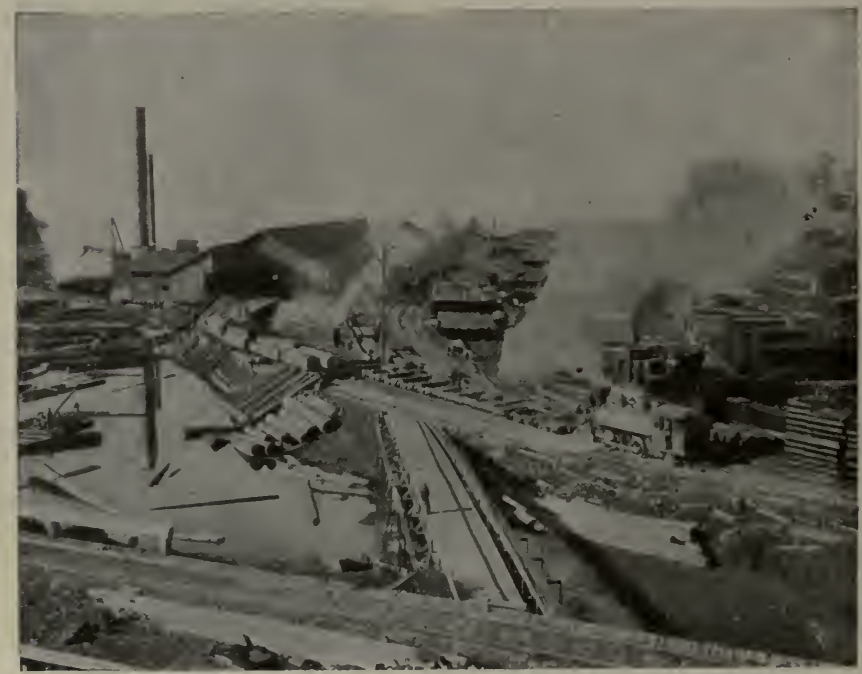

FIG. 34.-A sawmill, log pond, and lumber yard. Northern California.

over metal rails; often they are rolled into slides built of other logs, and either move downhill by their own weight or are dragged along by horses, cattle, or steam. In southern swamps the logs are sometimes swung up by a wire rope suspended from the trees, and so are loaded on the great flatboat which carries them to the mill. 
Bul 24, Bureau of Forestry, U. S. Dept. of Agr.

PLATE XIV.

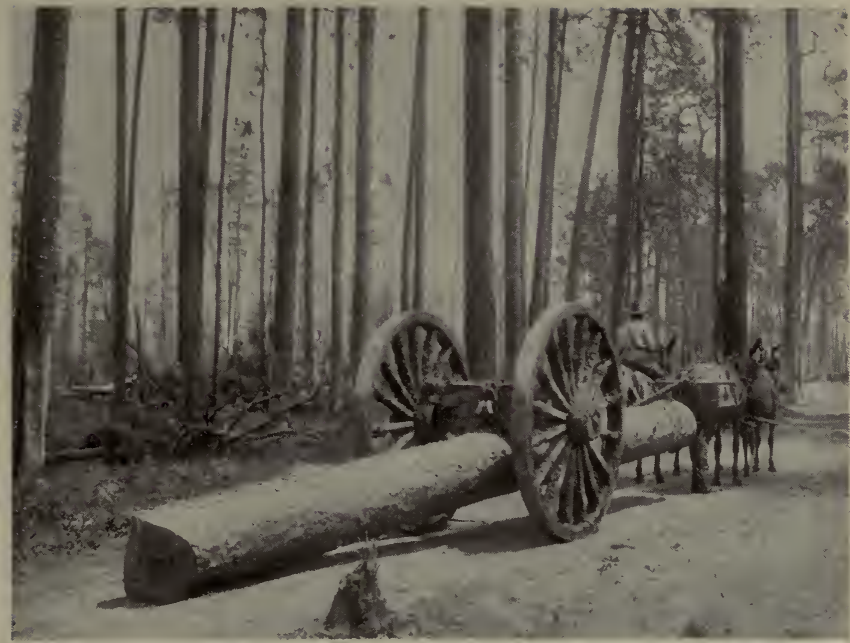

Fig. 1.- hauling loblolly pine. South Carolina.

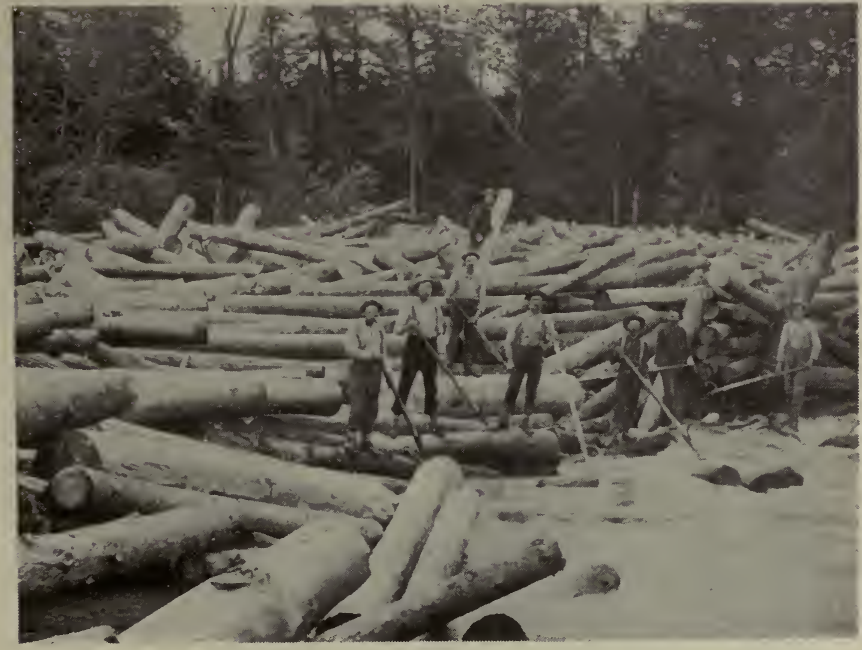

Fig. 2.-River Drivers at Work on a log jam. Minnesota. 
Bul 24, Bureau of Forestry, U. S. Deot. of Agr.

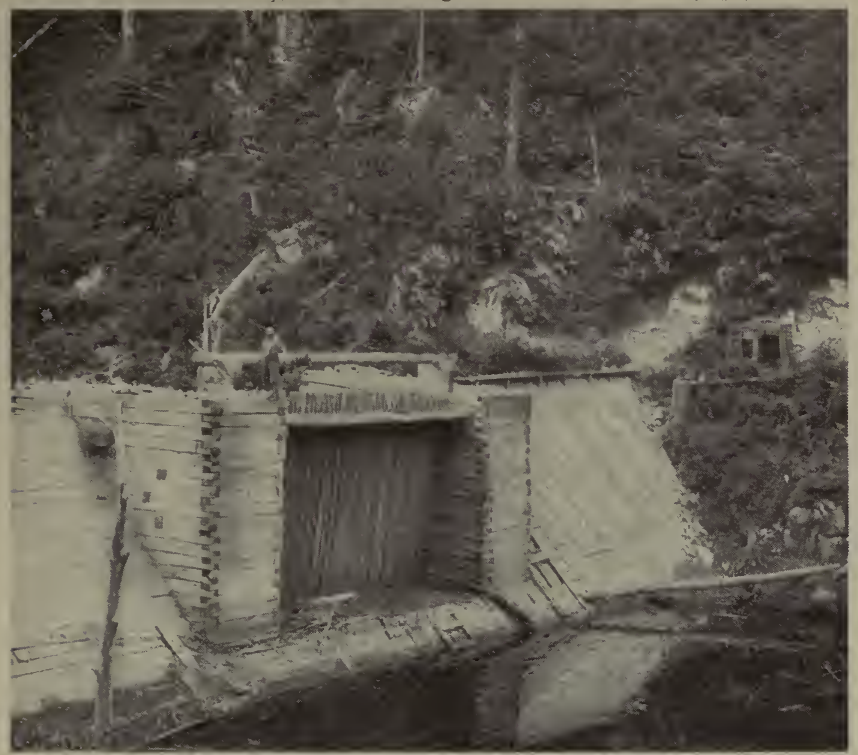

Fig. 1. - Interior of a Splash Dam. north Carolina.

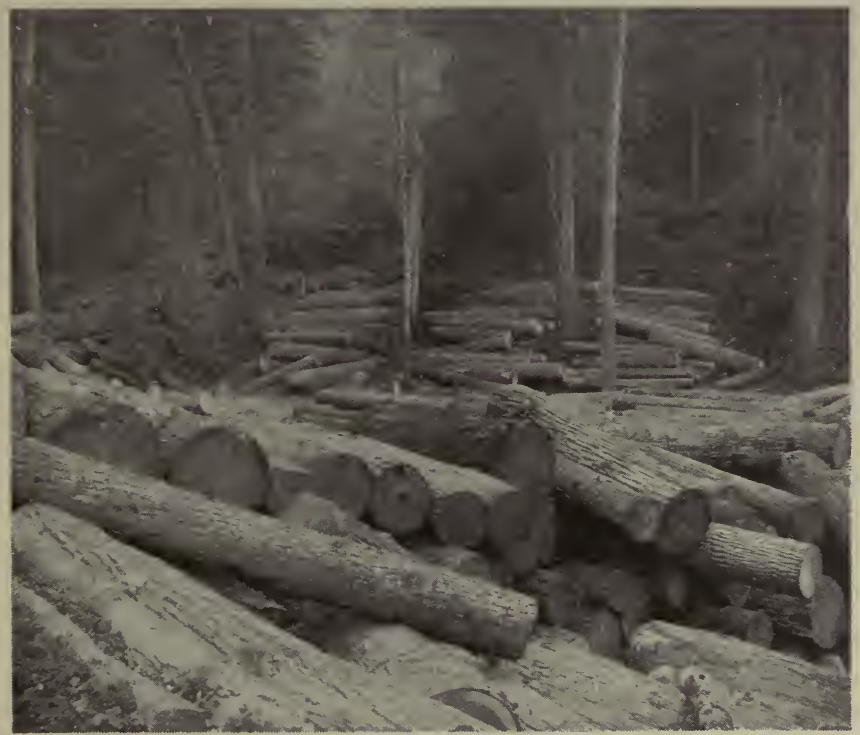

Fis.. 2.-Logs in the Stream bed Waiting for the Splash. North Carolina. 

At the mills the logs are cut into lumber by various kinds of saws. Of these the circular saw is still very widely used, although the wide bite or kerf which it cuts in the $\log$ makes it very wasteful of timber. A large circular saw makes a kerf a quarter of an inch wide, so that in eutting four one-inch boards enough wood to make a fifth hoard is ripped into sawdust. Band saws are far less wasteful, for they are thinner

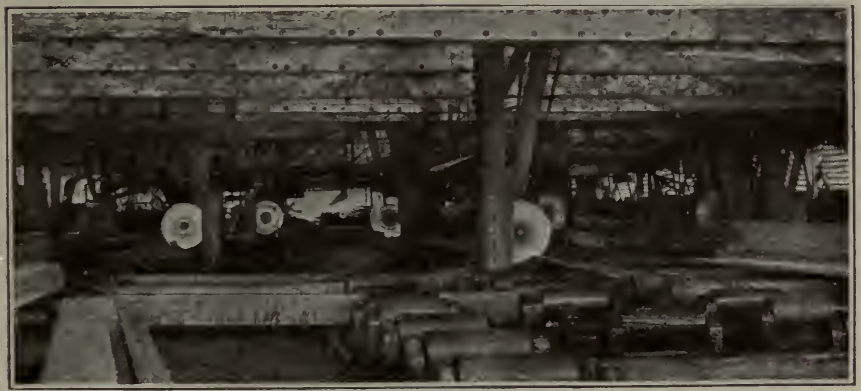

FIG. 35.-Circular saws (edgers) in a Puget Sound sawmill.

and make a narrower kerf. Hence they are taking the place of the circular saws, although they do not work so rapidly. Many mills, in addition to their band saws or circulars, use gang saws, which cut out several boards at the same time.

Besides lumber the best sawmills produce great quantities of lath and shingles, made either from small logs called "bolts," cut specially for that purpose, or from slabs, edgings, and other pieces of wood which might otherwise be wasted. But in spite of every effort to prevent waste in the mill, by using sawdust and other 
refuse for fuel, and in other ways, very many thousands of tons of wood a year are thrown into great burners as the cheapest method of getting it out of the way.

When the lumber has been sawed it may be piled and seasoned in the rard or kiln dried before it is sent to market or sold at the mill. Some sawmills on

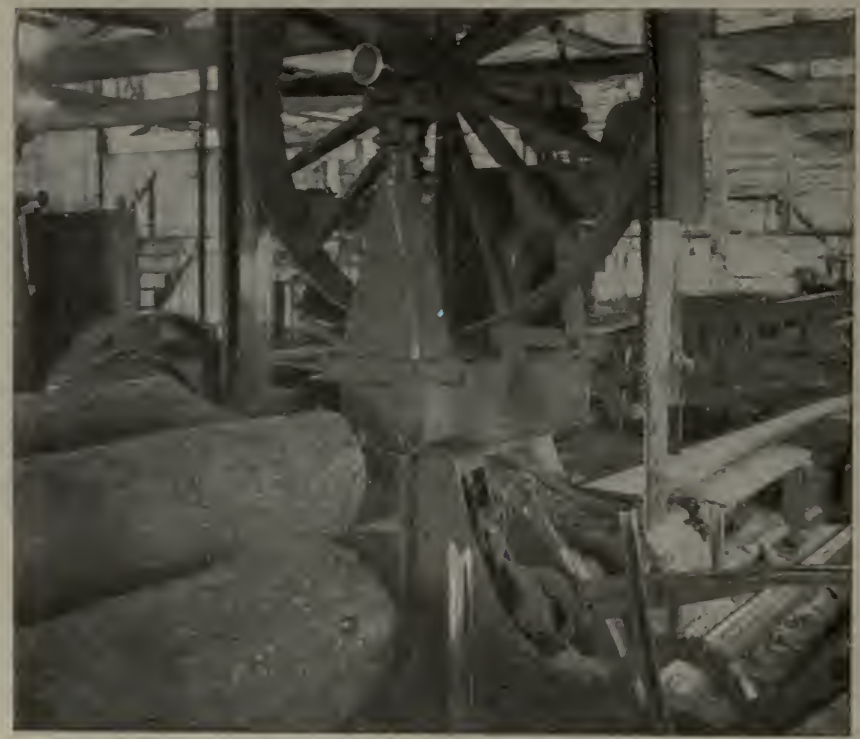

FIG. 36.-A band saw. Virginia.

Pugret Sound are built on piles over the water, so that the lumber is loaded into vessels directly from the saws. Others load their product on the cars and distribute it by rail. Still others on the Pacific slope float their timber away in a narrow wooden trough called a flume, through which flows a rapid stream of water. (Sce 


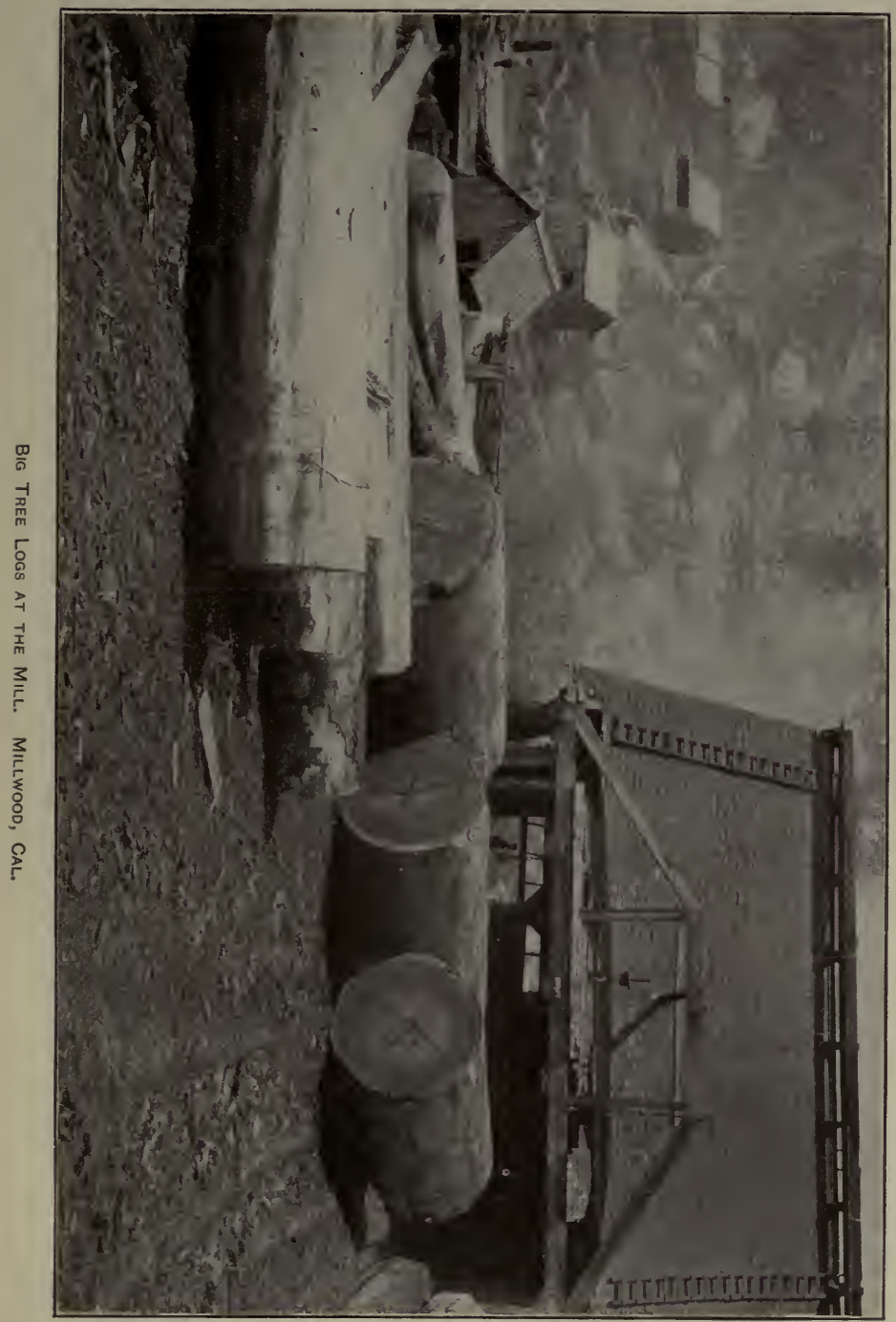





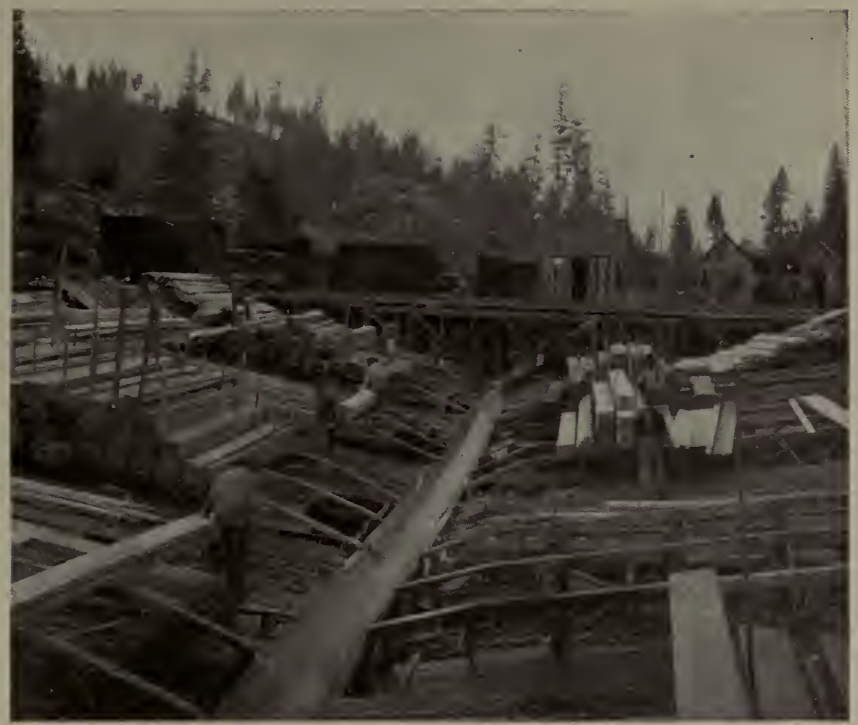

Fig. 1.-The Head of a lumber flume. California.

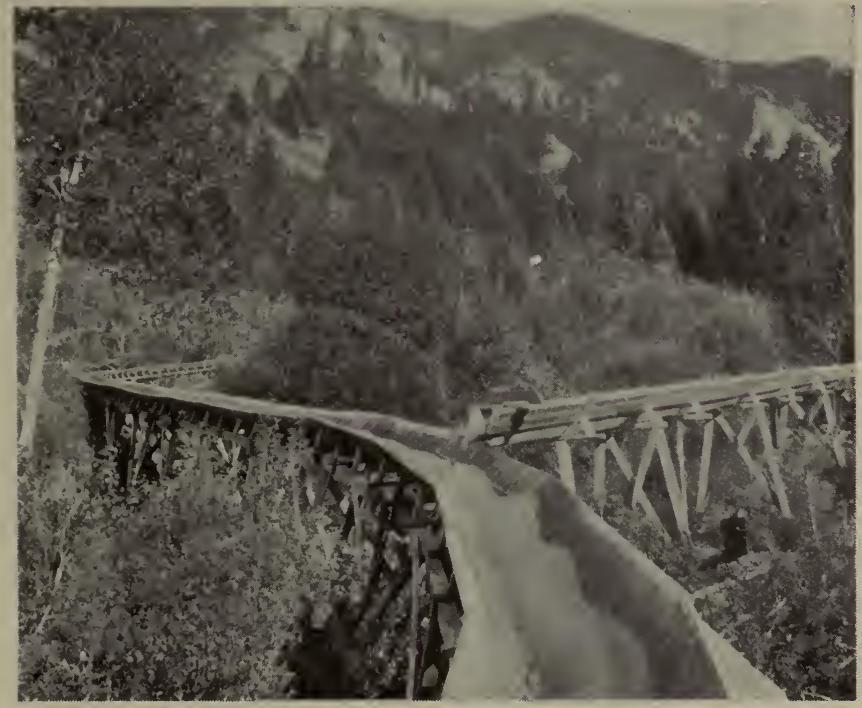

Fig. 2.-The flume in the Mountains. California. 

Pl. XVII.) These flumes are sometimes orer 40 miles in length, and cost almost as much to build as a railroad. Many sawmills have connected with them planing mills or woodworking factories of other kinds, so that the rough lumber from their saws is changed into the form of a finished product before it reaches the market.

WASTE IN LUMBERING.

This is very briefly the way in which a tree gets into the market at the end of its life. At every step there is some waste. Although it may be sound throughout, the lumbermen in the woods can take but a portion of it, often leaving a part of the trunk and all of the top to rot on the ground. When each $\log$ comes to the saw there is a further loss of nearly all the slabs and edgings and all the sawdust that is not used for fuel. On the average it is doubtful whether more than half of the cubic contents of a standing tree is

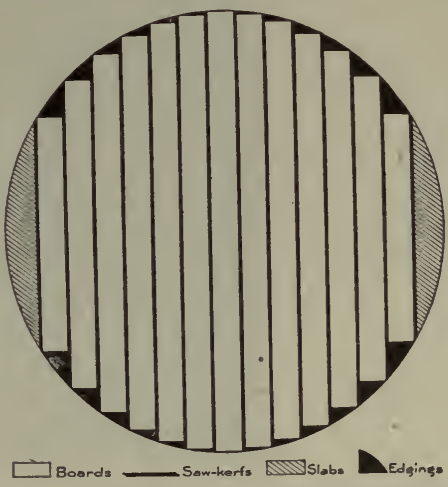

FIG. 37.-Diagram to show the sawing of a $\log$. finally used. As prices rise and as conservative lumbering comes to be generally practiced, the greater part of this enormous loss will be avoided, but it can probably never cease altogether. 


\section{PIANTING.}

It has often been proposed to plant trees in order to repair the damage clone to the forests by the lumbermen. Tree planting is most useful in all the treeless or scantily wooded portions of our country where planted

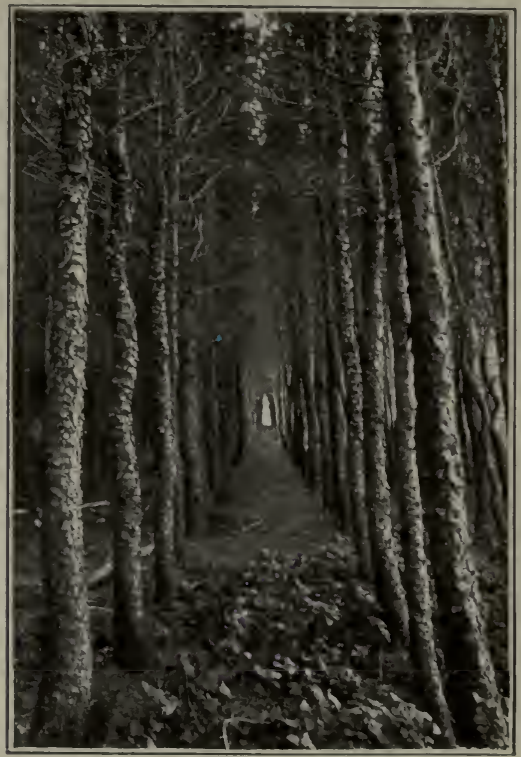

FI(i. 38.-A European larch grove in western Minnesota. Cost of planting per acre 17 years ago, \$64.45. I'resent value per acre, \$484.

- trees will grow, and wherever forests have been very severely injured or destroyed, but it is generally far too expensive to take the place of conservative lumbering in regions already forested. An acre of growing natural forest can be bought in nearly every forested part of 
our country for less than it would cost to plant, $t$ feet apart, an acre of seedlings a few inches high. The true way to sare the forests is not to plant new ones, but to protect and rightly use those which are standing now. The extension of the forest to regions which are without it is a most important task, but it must not be confounded with the conservative use of the forests now standing. For such use there is no substitute whatever.

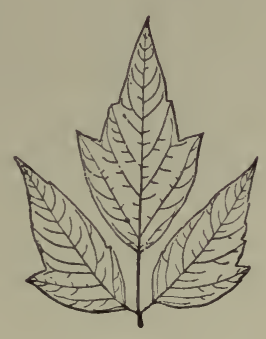




\section{C'HAPTER III.}

\section{THE WEATHER AND THE STREAMS.}

The central point of public interest in forestry in the United States was until recently the influence of forests on climate. It is natural that the connection between the immense forests and rast plains and the wonderfully various climates of this continent should have awakened attention. It is a matter which is easily written and talked about without any thorough understanding of forestry itself, and in this it differs from other branches of the subject. In dealing with the weather it touches a thing which affects the daily life of everyone, and which, to very many. holds the balance between porerty and prosperity. It is therefore unfortunate that so much of the writing and talking upon this branch of forestry has had little definite fact or trustworth observation behind it. The friends and the enemies of the forest hare both said more than they could prove. Both have tried to establish the truth of their opinions by referring to observations of temperature and rainfall which cover too short a time to prove anything, or by hearsay and general impressions, which are not to be trusted in such matters. Such discussions make nothing clear except that the pith of the matter has not been reached by either party. 
FORESTS AN1) CLIMATE.

The discussion of forest influence on climate began in this way. When the French revolution broke out in 1789 , the old restrictions on the management of private forests were done away. A wholesale cutting of these timberlands promptly followed, and as early as 1792 the consequences began to be observed. The question of forests and climate was then raised for the first time; but questions of this kind can not be answered without long and careful observations. Such observations were begun by Becquerel in France and Krutsch in Germany about the middle of the last century, but it was not until 1867 that a satisfactory way of making them was derised. This was the system of double stations-one within the forest, the other at a distance in the open. It was first put in operation by Professor Ebermayer, now of the Bavarian Forest School. By this means the amount of moisture and heat in the forest may be compared with that in the open, and in the end a full and satisfactory answer will probably be reached.

In order to find how great the influence of forests on climate may be, we must first see what are the factors which make climate. Then we may ask which of these factors can be affected by the forest, and in what way.

The climate of any place on the earth's surface results from the action of the sun's heat upon it. Climate is the average condition of the weather. It depends, first of all, on the distance of a place from the equator and its elevation above the sea. Secondly, it depends on the distribution of land and water, the relief of the 
land, whether Hat, hilly, or mountainous, and the character of the surface covering. These are all connected with the temperature in a special manner. Lastly, it is affected by the winds and the moisture of the atmosphere. Now, it is clear that of all these factors of climate the forest can influence only the wind, the moisture, and the surface covering; but heat (with

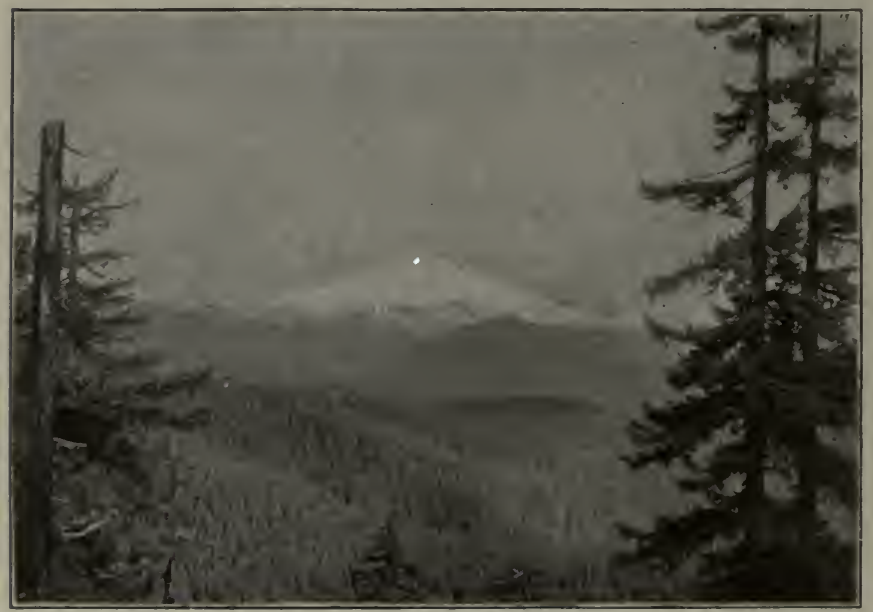

FIG. 39.-The forest eover. Oregon.

which the surface corering has so much to do), noisture, and wind are the three things which change when we say that the weather changes. These are just the points where a change due to the forest would have most effect on daily life. The influence of the forest is exerted upon them in two ways:

First. The forest cover intercepts the rain and the rays of the sun, checks the movement of the air, and reduces the radiation of heat at night. 
Second. The waste from the trees and from certain plants which grow only in their shade forms the forest floor, which has much to do with the movement of water on the ground and within it. The influence of

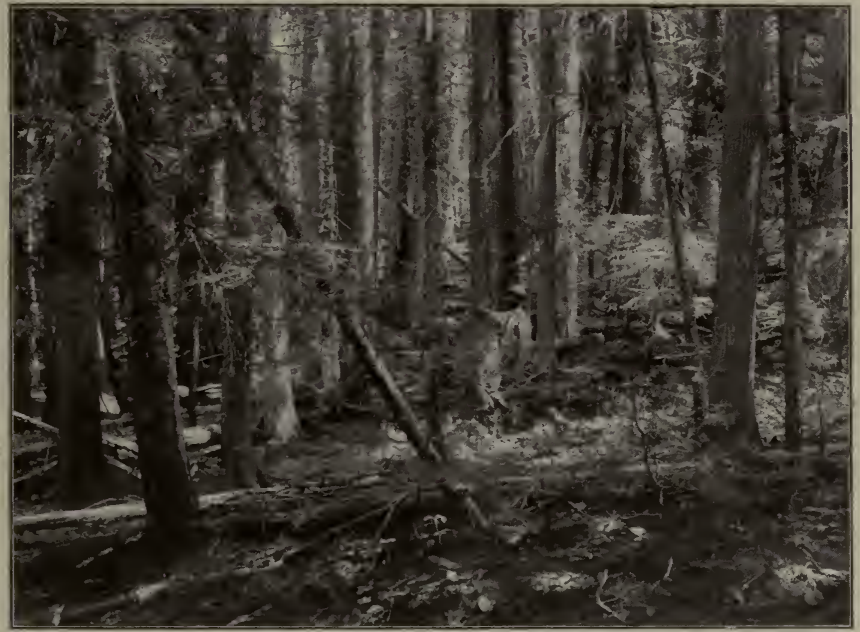

FIG. 10.-The forest floor. Idaho.

the forest corer and the forest floor appears in the temperature of the air, the evaporation of water, the rainfall, and the course of the rain water after it has reached the earth.

EFFECT OF FOREST COVER ON TEMPERATURE.

So far as the influence of the forest is concerned, the temperature of the air is affected chiefly by the forest cover. The leaves, which compose the greater part of 
the cover, contain from 50 to 70 per cent of water. More heat is required to raise the temperature of a pound of water one degree than for a pound of almost any other substance, and so it happens that bare soil or rock exposed to the rays of the sun becomes heated many times faster than the water in the leaves. While the heated rock or soil was warming the air about it the forest cover would still be absorbing heat and keeping the air below it cool. The leaves of the cover also tend to cool the air by transpiration, which is the evaporation of water from the leaves. This is true because heat is required to change water into water vapor, and a part of the sun's heat is taken up for this purpose. In these two ways the forest cover acts somewhat like a surface of water.

The growth of the tree itself also helps to cool the air. When the leares take carbonic-acid gas from the air they break it up and foree its earbon into new rhemical compounds, which are then stored away as new material in the tree. So with water and the other substances upon which the plant feeds. But the elements are less at ease in these new compounds, and heat is required to force them to make the change. When we burn wood for fuel we are simply getting back again the heat which was used to bring about this change. So we may say roughly that the air about the tree during its lifetime has been deprived of as much heat as would be given off if the whole tree were burned.

The effect of the cooler air of the forest is felt to some distance in the open country. During the day, in calm summer weather, when the air is warmer than the tree tops, it is gradually cooled by contact with the 
cooler leaves and twigs. In cooling it becomes heavier and falls toward the ground. A rising current of warmer air is formed to supply its place, and so the colder air flows off along the surface into the open country and causes local breezes. At night the air currents are reversed. The air in the forest is then warmer than the air outside, because the cover checks the radiation of heat, and so the colder air mores from the open country toward the woods. In these ways the influence of the forest is felt at a distance.

The amount of this cooling of the air has been measured in certain places. It is naturally found to be greatest in summer; while in winter and at night the air in the tree tops is a little warmer than in the open. It is important toadd that the cooling effect of the forest is greater than the average in the mountains, and less in the plains.

\section{EXTREMES OF HEAT AND COLD.}

The extremes of heat and cold are moderated by the forest. Observations on this point have been made, for example, in Bavaria and $W$ ürttemberg. They showed that the lowest temperature of every day in the year was higher, on an average, by nearly $2^{\circ}$ in the forest, while the highest temperature was lower by nearly $4^{\circ}$. The greatest heat of the day in the summer was $7 \frac{1}{2}$ less in the forest than outside. Prussian observations showed that for ten years the greatest heat of the day in July was, on an average, nearly $6^{\circ}$ lower in the forest, and the greatest cold of the night in January nearly $3^{\circ}$ less than outside. It should not be forgotten that the latitude, the eleration, and the exposure had a 
powerful influence on these differences, which are also greatly affected by the kind of trees and the density of the forest.

It must be borne distinctly in miad that the figures given above are reliable only for the places in central Europe where they were observed. But the principles on which they depend are just as true in America as they are in Europe. Natural laws are the same the world over. It is safe to conclude, then, that in the Inited States the forest modities the temperature of the air in certain ways and for certain reasons, both of which we have seen. Just how great this influence is in different parts of this continent it is as yet impossible to tell. But it is probably greater on the average than these observations indicate, for two reasons: First, the extremes of heat and cold, moisture and dryness, are much greater here than in central Europe. and changes are more sudden; second, in most of the double stations mentioned ahove the station outside the forest was within less than a mile of it, and thus likely to be influenced ly the cooler air currents flowing from it: that is, the real effect of the presence or absence of woods over large stretches of country is probably greater than these observations show.

A system introduced in Austria is expected to give a clearer idea of the distance to which the forest influ. ence reaches. It consists of lines of stations beginning in the center of a large forest and extending step by step into the open country beyond.

MOISTURE: IN FOREATI AIR.

The moisture of the air is greater in the forest than outside. The absolute quantity of water vapor in a 
rubic foot of air is generally the same in both places, hut the forest air is cooler, and therefore its relative humidity is greater. Relative humidity is the amount of vapor actually in the air, expressed as so much per cent of all it could hold at the same temperature. The amount of water that the air can hold changes when the temperature changes, but in such a way that air cooled until it is only half as warm as before can hold much less than half as much vapor. If a hot and a cold strean of air, both saturated with water vapor, meet and mix, the mixture can no longer hold as much rapor as the two streams separately, and a part is condensed, usually in the form of rain or snow. German and Swiss observations have shown that the average humidity is greater in the forest by from 3 to 10 per cent. This difference increases with the altitude above sea level and the density of the forest cover. The increase of humidity explains why dew is more frequent in the neighborhood of the forest than at a distance.

\section{EVAPORATION.}

The water which falls to the earth from the atmosphere had first to be evaporated, so that year by year the quantity of water which the air takes from the surface of the globe by evaporation is the same as that which falls upon it in the shape of rain, hail, snow, and dew. The effect of the forest on this great movement of water is to detain more of it on those portions of the earth which are sheltered by trees. It does this partly by tending to increase the rainfall, but its effect in lessening the loss of water through evaporation is probably much nore important. The colder and moister

$$
1116-05-7
$$


air of the forest has less capacity for taking up water rapor than that of the open country. It is also quieter, which means that the winds are less active in replacing saturated ail with air which can still take up more water. The forest acts powerfully in checking the force of the winds because the elastic swaying of the twigs and branches is a very effective hindrance to

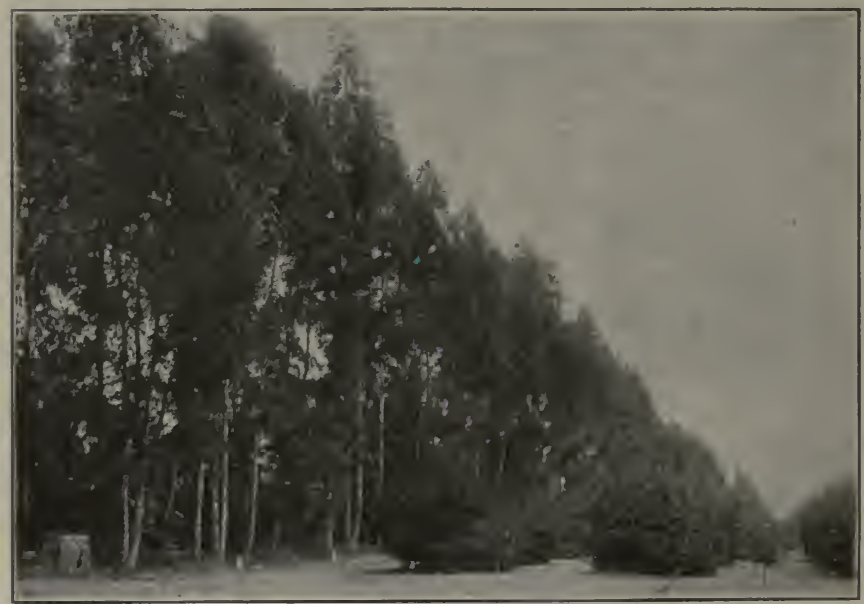

Fig. 41.-A windbreak. California.

the movement of the air. Strong winds, although they are often dangerous in themselves, do most harm hy drying up the moisture in the soil and in the plants which grow from it. Thousands of miles of windbreaks have been planted by farmers in the western parts of this country to protect their crops and homes against the wind. 'These windbreaks serve a most nseful purpose, hut they are naturally far less effective in 
preventing evaporation than the forest itself. So great is the power of the latter that direct observations made in Bavaria and Prussia showed that evaporation from a free surface of water in the forest was only 40 per cent of that in the open.

The presence or alssence of leaf mold has a powerful effect on the amount of eraporation from forest soil.

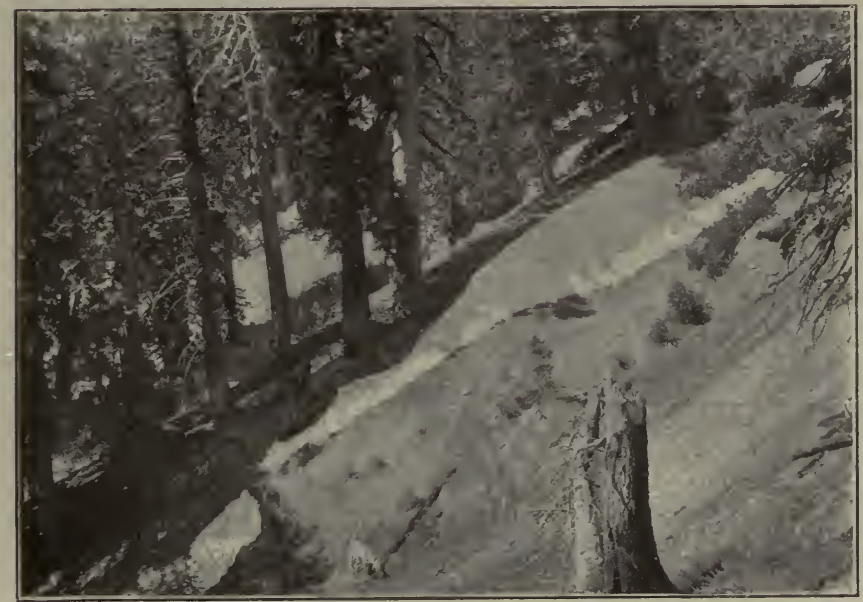

FIG. 42.-A snow bank evaporating. San Gabriel Mountains, Califorria.

The experiments of Dr. Ebermayer, a famous German forest meteorologist, showed that eraporation from forest soil without a layer of mold was 47 per cent of that from soil in the open, while with a layer of mold it was less than half as much, or 22 per cent. The greater the altitude above the sea the greater is the effect of the forest in preventing evaporation. This is a powerful reason for preserving mountain forests at 
the headwaters of streams, especially in the Rocky Mountain regions of the United States. Evaporation is there so active that great banks of snow lying in the full glare of the sun often disappear without melting even enough to moisten the ground on the hillsides below them. Vast quantities of water evaporate in this way without ever reaching the streams. Measurements made by the Bureau of Forestry show that evaporation from snow may be four or five times as great as from water under like circumstances.

\section{RAINFALL.}

'The causes of rain are for the most part wholly herond the reach of influence from the forest. Such are the great currents of warm and cold water in the ocean, the direction of the prevailing winds. and the presence or absence of mountain ranges. But there are two reasons which lead us to believe that forests do affect the rainfall. These are their colder and moister air, and the resistance which they offer to the motion of the winds. A great number of observations has been made in different parts of the world to discover how much the rainfall really is affected by the forest, but for several reasons no generally accepted result has yet been reached. In the first place, accurate observations on rainfall are not easy to make. The height above the ground at which a rain gauge is placed affects it rery seriously. A rariation of 10 feet in height will often make more difference in the amount of rain caught than most observers claim for the whole action of the forest. The rainfall of two stations at unequal heights above sea level is some- 
times wrongly compared, because the difference in rainfall may be caused by the difference in altitude. Finally, the best observations that have been made point to different conclusions. For example, measurements taken in Prussia go to show that there is an increase of rain over the forest, and that it is greater the higher the station. Thus, near the level of the sea it was only 1.25 per cent greater than over the open country, while at altitudes between 2,000 and 3,000 feet it reached 43 per cent. Observations made at Nancy, in France, which lies about 700 feet above the sea, show an average yearly increase of 16 per cent. The Bavarian observations, on the contrary, do not indicate more rain orer the forest. The best evidence at hand fails to show a decrease in rainfall over the United States in the last hundred years, in spite of the immense areas of forest that have been burned and cut. But it should not be forgotten that most of those areas have grown up again, first with brush, and afterwards with trees, so that the proportion of land covered with leaves is still very large in all that part of the country which was once under forest. In India, again, a large amount of statistics has been collected which leads to the conclusion that forests do influence rainfall. The truth probably is that more rain falls over the forest than over open country similarly placed, but how much more it is impossible to say. The excess falls chiefly in the form of summer showers. One of the best authorities has estimated the difference at 10 per cent.

FALLEN RAIN.

Whatever doubt there may be about the action of the forest in producing rain, there is none about its 
effect on min water after it has fallen. When rain falls over a dense forest from less than one-tenth to about one-fourth of it is caught by the trees. A small part of this water may reach the ground by rumning down the trunks, but the greater part of it is evaporated and so increases the humidity of the air. That which passes through the crowns falls upon the forest floor, which sometimes has an absorbing power so great that it can hold for a while a rainfall of 5 inches. Yet

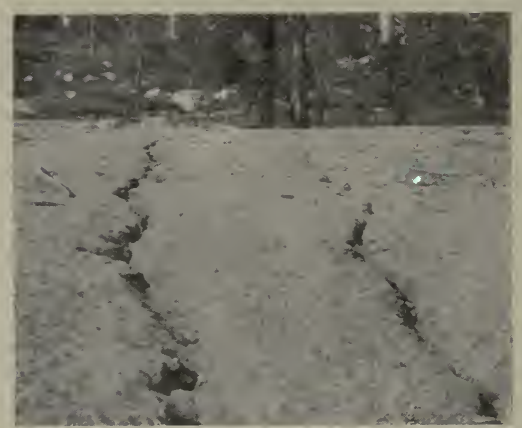

FIg. 43.-The beginning of erosion in soil tramped bare by stock. Sierra Nevada Iountains, California. this water does not remain in the porous floor, but in the end runs off into the streams, or is eraporated, or sinks into the ground. That which gets into the ground is either taken up by the roots or goes to feed the springs and watercollrses.

Rain which falls over a bare slope acts differently. It is not caught by the crowns nor held by the floor, nor is its flow into the streams hindered by the timber and the fallen waste from the trees. It does not sink into the ground more than half as readily as in the forest, as experiments have shown. The result is that a great deal of water reaches the streams in a short time, which is the reason why floods occur. It is therefore true that forests tend to prevent floods. But this good influence is important only when the forest covers a large part 
of the drainage basin of the stream. Even then the forest may not prevent floods altogether. The forest floor, which has more to do with the fallen rain water than any other part of the forest, can affect its flow only so long as it has not taken up all the water it can hold. That which falls after the forest floor is saturated runs into the streams almost as fast as it would orer bare ground.

An unforested drainage basin in the San Bernardino Mountains of southern California was found by the Bureau of Forestry to discharge the rain it received more than twice as rapidly as similar forested basins near by. In consequence, the stream in the former

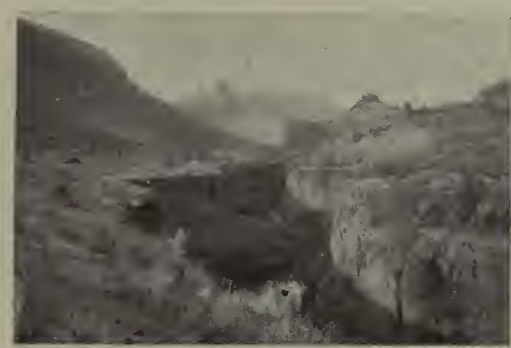

FIG. 44.-Rapid erosion in deep fine soil. went dry, while the streams in the latter were still flowing abundantly. (See Pl. XVIII.)

In these ways it happens that in mountain countries, where floods are most common and do most harm, the forests on the higher slopes are closely connected with the prosperity of the people in the valleys below.

Water in motion was nature's most powerful tool in shaping the present surface of the earth. In places where the slopes are steep, the structure of the ground loose, and the rainfall abundant, water may work very rapidly in cutting away the heights and filling the ralleys. The destruction of the forest in such a region exposes the surface to the direct action of falling rain 
and is certain to be followed by the formation of torrents. The danger is greatest when the soil has been laid bare by the browsing and the hoof s of grazing animals, among which sheep and goats are especially destructive, or where the forest floor has been burned away.

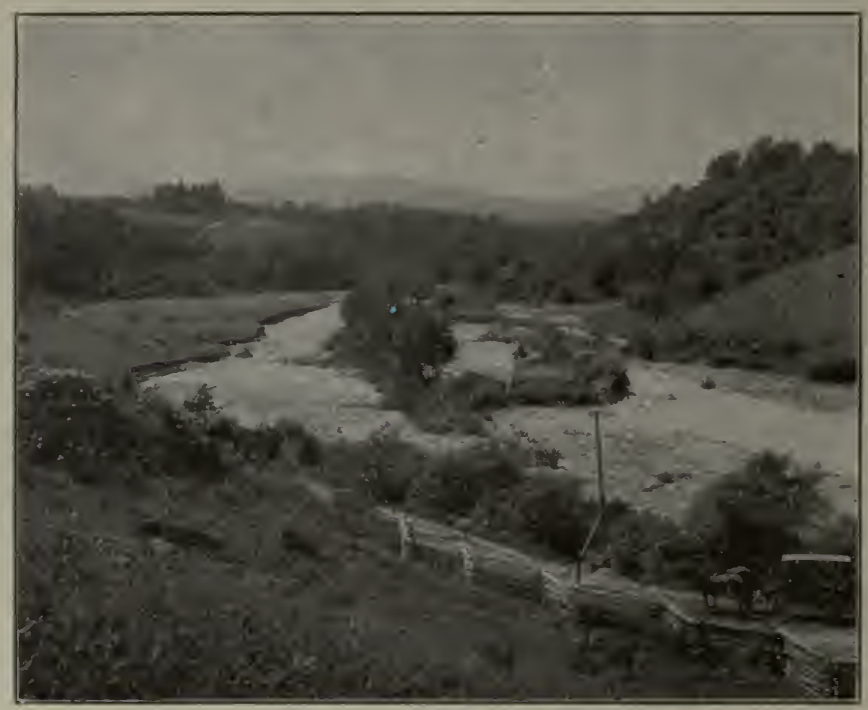

FIs. 45.-Destruction by floot. North Carolina.

When these conditions are both present, as in parts of the Sierra Nevada Mountains of California, of the Cascade Range in Oregon, and in many other parts of the West, the prosperity of the valleys is in serious danger. Fire and overgrazing on the mountains combine to endanger the future water supply of irrigated or irrigable areas in the vallegs helow. 
When rain falls over mountains which have so been deprived of their natural protection it is no longer caught and held back by the trees and the forest floor. The roots, which were once the strongest means of binding the soil together, now are gone and leave it without protection against the rushing water. Heavy rains or sudden thaws swell the streams with

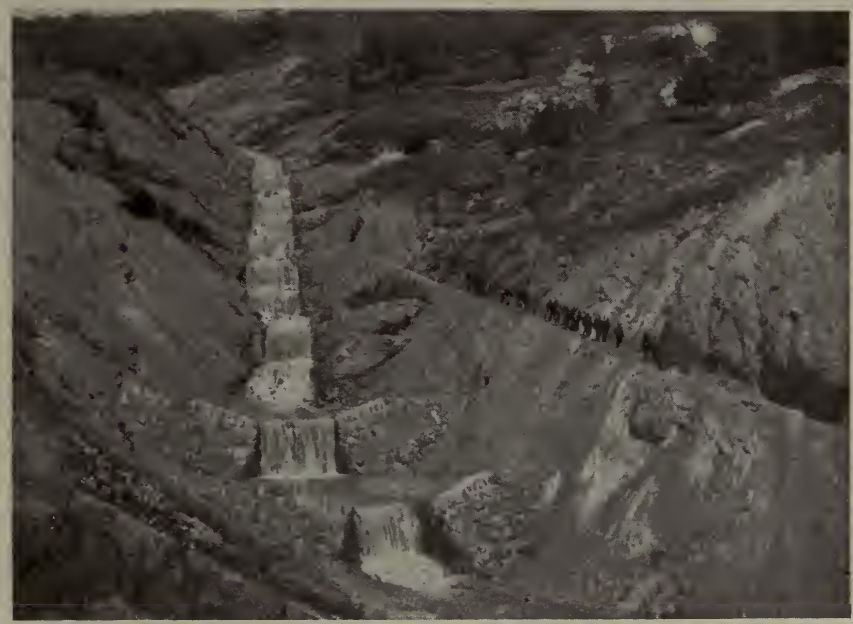

FIG. 46.-Masonry dams built to control a torrent. Students of the French forest school at the right. Alps of southern France.

marvelous quickness, and give them a wonderful power to cut away their banks. Where the waterway is very steep such a flood often carries with it many times its own weight of earth and stones. As it nears the valley it breaks from its bed and makes new channels, or spreads over the lowlands. The current loses its swiftness, and its load of stones and sterile earth sinks to 
the bottom, the hearier pieces first. Where it falls the beds of rivers are filled up and fertile lands are covered with pebbles and sand.

For a time after such a flood the streams are usually low. becanse the water which should have fed them for weeks or months has run off in a few days. This may bo quite as serious a matter for the farmers as

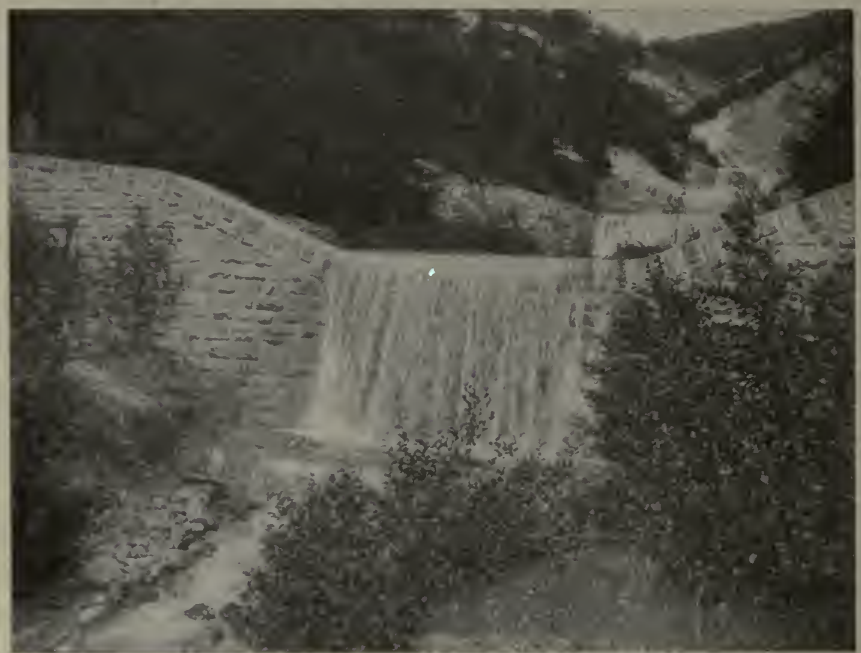

FIf. 17.-Plantation of European alder in the bed of a torrent controlled by dams. This torrent is now extinet. Alps of southern France.

the destruction of their tields, as for example in places like southern California, where the rops depend on irrigation with the water of streams which rise in the mountains. Torrents have begun to form there in the San Bernardino Mountains, and have already carried stones and sand into the orange groves and ren into the towns of the San Gabriel Valler. Before the 


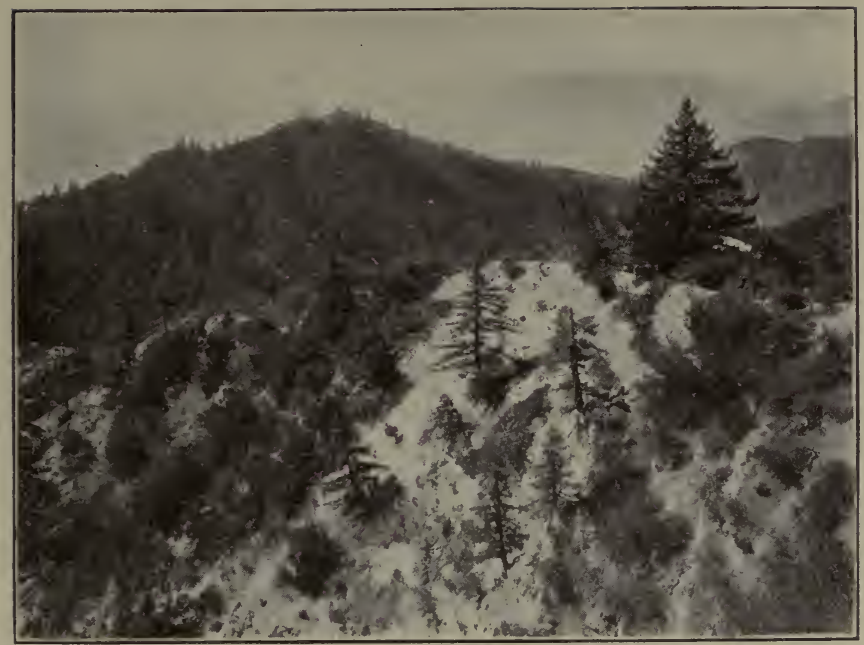

Fis. 1.-Foresteo Watershed in the San Bernardino Mountains, SOUTHERN CALIFORNIA.

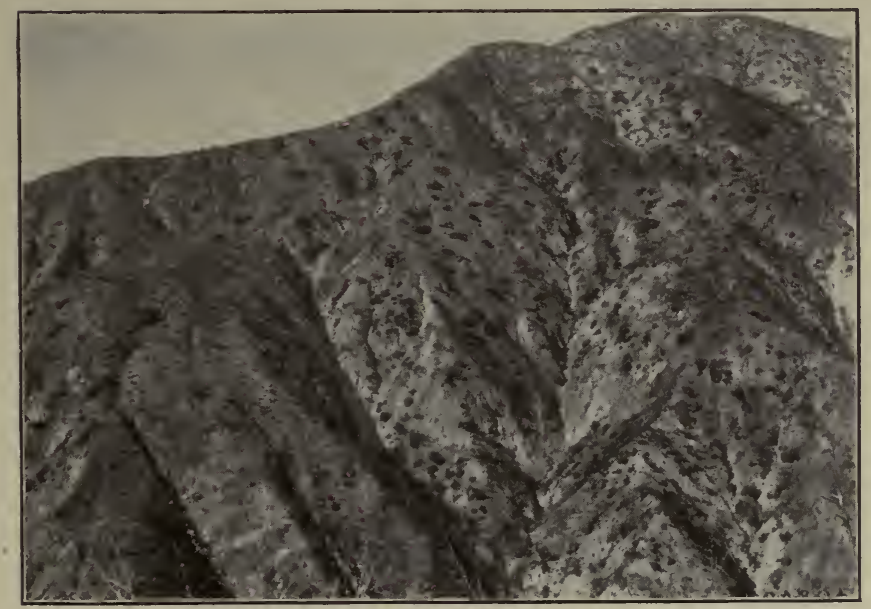

Fig. 2.-Unforested Watershed in the San Bernardino Mountains, SOUTHERN CALIFORNIA. 

water of the San Gabriel River was so largely taken out for irrigation it was rapidly cutting away the fertile land on either side of its shifting bed, and it seemed likely that serious loss of property would follow. This is the direct result of fire and grazing in the mountains.

The pasturage of sheep in the Alps of southern France was the chief cause of the destructive torrents with which the French Government has been struggling for many years. The direct loss to the French people has been enormous, and in addition the work of correction alone has cost upward of $\$ 35,000,000$. Although wonderfully successful hitherto, it is still far from finished.

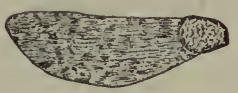




\section{CHAPTER IV.}

\section{FORESTRY ABROAD AND AT HOME.}

\section{FOIESTRY ABROAI).}

Except China, all civilized nations care for the forest. Until recently the United States ranked nearly with China in this respect, and our country still remains far behind the progressive modern nations in nearly all that relates to the protection, preservation, and conservative use of the forest. Japan has a welldeveloped forest service and a national forest school. In Austria, Italy, and Norway and Sweden government forestry is a well-established portion of the national life. Turkey, Greece, Spain, and Portugal give attention to the forests. Russia, dealing like ourselves with vast areas of forests in thinly peopled regions, but by methods wholly different from our own, is drawing enormous revenues from the systematic care and use of the forests. In Germany the scientific treatment of forests has reached, perhaps, its highest development. The forester's of France have perfected a most practical and effective general system of forestry, and have created the difficult art of controlling the floods of mountain torrents by planting trees. The Republic of Switzerland, by the use of methods most instructire to citizens of the United States, has dereloped a type 
of government forest policy more worthy of our attention and imitation than any other in Europe. In Australia and New Zealand forestry has already made important advances. In Canada the English have made real progress in forestry; the government sells the timber from its forests, but retains possession of the lands and employs fire guards; at the Cape of Good Hope they have an excellent forest service; in British India they have met and answered many questions which still confront the American forester, and in a little more than thirty years have created a forest service of great merit and high achievement. The United States has scarcely yet begun.

THE FOREST IN EARLY TIMES.

In rery early times the forest was preserved for the game it contained. Forestry then meant the art of hunting, and had very little to do with the care of trees. Even the word forest, which really comes from the Latin foris, meaning out of doors, was thought in England to be derived from the fact that it was a place given up to wild animals for rest. But gradually the forest came to be considered more than the game, and the serious study of forestry began.

\section{MODERY FORESTRY.}

Forestry as a science is of comparatively recent origin, although a work in which all the European trees are described was one of the earliest printed books. Until the end of the eighteenth century forestry was discussed chiefly by men who were eitner scholars or practical woodsmen, but who were not both. Then appeared Hartig and Cotta, two men_who 
united these points of view, and their writings are at the base of the whole modern growth of the subject. Both were German. Each covered the whole field as it was then understood, and together they exerted an influence which has not been approached by any other authors since. From Germany their teaching spread to France, and early in the nineteenth century their doctrines were introduced into the French Forest School at Nancy by Lorentz, who, with his successor, Parade, was the founder of modern forestry in France.

Under the feudal system, which was finally destroyed in France by the revolution of 1759. the forest was the property of the feudal lord. In order to make the life of their serfs, who were useful both as taxpayer's and as fighting men, easier, and so increase their number, he gave them the privilege of taking from his forest the wood which they required. For similar reasons the wealthy religious houses, like that of the Grande Chartreuse, made grants of land and of rights in the forest. But after a time the number of peasants increased so much that their wants absorbed nearly the whole produce of the woodlands. Then it was found necessary to limit the prescriptive rights to forest products by restricting them to certain parts of the forest, or to make an end of them by exchanging them for the absolute ownership of smaller areas. Thus many of the communities, to which, and not to individual peasants, these rights belonged, came to possess forests of their own. But the communes, as they were called, managed their forests badly, and about three hundred years ago the Government was forced to intervene. Under the management of ofti- 
cers of the Government forest service, the results from the communal forests have been excellent. At present these forests not only supply fuel to the villages which own them, but in some cases they produce enough to pay all the village taxes as well.

\section{Germany.}

Germany still holds the high position in forest science which began with Hartig and Cotta. The German forest schools, of which there are seven of the higher grades, are still among the very best, and the study of forestry, both in the schools and in the forest experiment stations, is eagerly pursued. The forests in Prussia, Saxony, and other German States are admirably managed, and yield important returns. The total value of the German forests, public and private, is said to be about $\$ 4,500,000,000$.

\section{France.}

Forestry in France has long been associated with the names of famous men. Henry of Navarre and his friend and minister, Sully; Palissy, the great potter, who called the neglect of the forest prevalent in his time "not a mistake, but a calamity and a curse for France;" Colbert, the minister of Louis XIV; the botanist Duhamel du Monceau; Buffon, the celebrated naturalist, are among the men to whom France owes the rise and progress of her present excellent forest policy. Their peculiar service was to lay the foundation, both in law and in public opinion, upon which modern forestry in France now rests.

The forests of the French Government are admirably $1116-05-8$ 
managed. They cover only about 2,750,000 acres, but they yield a net return each year of more than $\$ 2$ per acre. Besides handling their national forests with great intelligence and success, the French foresters have done much for the general progress of forestry. They developed the art of reforesting denuded nountains, and were the first to plant trees on moring sand dunes along the seashore. More than 150,000 acres of these dunes, which once were blown about by the wind until they orerwhelmed great stretches of fertile ground, and even threatened to bury whole towns, are now covered with forests of pine, and produce great quantities of turpentine, lumber, and charcoal.

\section{Sivitzeriand.}

In Switzerland forestry received attention from very early times. Neariy two hundred years before the discovery of America the city of Zurich began to make rules for the protection and management of the Sihlwald, a forest which it still owns, and which now yields an annual return of about $\$ s$ per acre. In the Canton of Bern a decree of the year 1592 warned the people against the wasteful use of timber and provided for the protection of the forest along various lines. It also directed that for every tree cut down a young one should be planted in its place. It is curious to find this mistaken prescription for the ills of the forest already in fashion more than three centuries ago. To save the forest every old tree must be replaced by muny young ones.

The first general forest law of Bern was passed as early as 1725 . It embodied the most important princi- 
ples of wise forest legislation as we know them to-day. But this was only one of a long series of forest laws in which, from the beginning, the idea of the importance of the forest to others besides its owner became steadily stronger. The citizens of .Bern have grown ever more willing to place restrictions on themselves for the benefit of the Commonwealth.

There were great floods in Switzerland in 1834, and they were the cause of a general awakening of interest in forestry. Somewhat later a federal forest commission was appointed. Since the appearance of its final report in 1861 the progress of forestry in Switzerland has been steady. In 1875 a federal forest inspector was appointed, and a year later the first Swiss forest law was passed. 'This law does not extend to the whole of Switzerland, but only to the Alps and the steeper foothills. In a country of steep mountains it is of first importance to guard the forests on the higher slopes. Consequently all the forests on these higher lands which serve to protect the lowlands against floods, avalanches, and other similar dangers of wind and weather are put in charge of the Swiss federal forest service.

A great saying of Landolt. - "Our forest laws," said Elias Landolt, a great and simple man, whose name stands first among Swiss foresters, "are intended to work more through instruction, good example, and encouragement than by severe regulations. This method is somewhat slower than one which should involve harsher measures, but the results achieved are more useful and lasting. When forest owners do something because they are convinced of its usefulness it is 
done well and with an eye to the future, but what they do under compulsion is done carelessly and neglected at the first opportunity. What they have come to learn in this way and have recognized as good will be carried out, and that better and better from year to year."

\section{British India.}

For many years after the British conquest forestry in India made very little progress. Much time was wasted in half measures, until in $1856 \mathrm{Dr}$. (now Sir Dietrich) Brandis was put in charge of the teak forests of Pegu. Heacted at once upon the idea of preserving them by making them pay. At first the output of teak had to be somewhat restricted, much against the will of the timber merchants of Rangoon, who protested that the business of their city would be ruined. But after this momentary check the teak trade of Rangoon grew until it was far greater than ever before, and it is now a chief and increasing source of the prosperity of that city.

The appointment of Dr. Brandis was the beginning of the Indian forest service. In 1866 he was made inspector-general of forests, and from that time progress was rapid. The Indian forest service now has nearly 300 superior officers and over 10,000 ranger's and forest guards. It has charge of about 200,000 square miles of forest, and produces a net revenue, after all expenses have been paid, of about $\$ 3,000,000$ a year. In addition, the forests furnish to peasant holder's of forest rights products whose value is estimated to be considerably greater than the whole cost of the forest service. About 30,000 square miles are effectively 
protected against fire, at an average yearly cost of less than half a cent per acre. These admirable results are especially interesting because India is like the United States in the great extent and variety of her forests and in the number and fierceness of forest fires.

FORESTRY AT HONE.

The forests of the United States cover an area of about $699,500,000$ acres, or more than 35 per cent of the surface of the country. Before so large a part of them was destroyed they were, perhaps, the richest on the earth, and with proper care they are capable of being so again. Their power of reproduction is exceedingly good.

In the Northeastern States, and as far west as Minnesota, once stretched the great white pine forest from which, since settlement began, the greater part of our lumber has come. South of it, in a broad belt along the Atlantic and the Gulf coasts, lies the southern pine forest, whose most important tree, both for lumber and naval stores, is the southern yellow pine. In the Mississippi Valley lies the interior hardwood forest of oaks, hickories, ashes, gums, and other hardwood trees. It is bordered on the west by the plains, which cover the eastern slope of the continental divide until they meet the evergreen Rocky Mountain forest which clothes the slopes of this great range from the Canadian line to Mexico. Separated from the Rocky Mountain forest by the interior deserts, the Pacific Coast forest covers the flanks of the Sierras, the Cascades, and the Coast ranges. Its largest trees are the giant sequoia 
and the great coast redwood, and its most important timber is the fir.

The forests of the Philippine Islands cover an area of more than $40,000,000$ acres. Their timbers, almost wholly different from those of the United States, are exceedingly raluable, both as cabinet woods and as construction timber. An efficient forest service was organized in 1898, and following its reorganization in 1902 a new and excellent forest law was passed in 1904 . The Philippine forest service costs but half as much as the revenue receired from the forests of the islands.

The island of Porto Rico contains a national forest reserve, the site of which was once covered with valuable hardwoods; but this forest has been much abused. Porto Rico, like the Philippines, has many kinds of wood valuable for cabinetmaking.

THE SETTLER AND THE FOREST.

When the early settlers from the Old World landed on the Atlantic coast of North America they brought with them traditions of respect for the forest created by generations of forest protection at home. The country to which they came was covered, for the most part, with dense forests. There was so little open land that ground had to be cleared for the plow. It is true that the forest gave the pioneers she."er and fuel, and game for food, but it was often filled with hostile Indians, it hemmed them in on every side, and immense labor was required to win from it the soil in which to raise their necessary crops. Naturally, it seened to them an enemy rather than a friend. Their respect for it dwindled and disappeared, and its place was taken by hate and fear. 
The feeling of hostility to the forest which grew up among the early settlers continued and increased among their descendants long after all reason for it had disappeared. But even in the early days far-sighted men began to consider the safety of the forest. In 1653 the authorities of Charlestown, in Massachusetts, forbade the cutting of timber on the town lands without permission from the selectmen, and in 1689 the neighboring town of Malden fixed a penalty of 5 shillings for cutting trees less than 1 foot in diameter for fuel. An ordinance of William Penn, made in 1681, required that 1 acre of land be left covered with trees for every 5 acres cleared. But these measures were not well followed up, and the needless destruction of the forest went steadily on.

FIRST STEPS IN FORESTRY.

More than a hundred years later, in 1795 , a committee of the Society for the Promotion of Agriculture, Arts, and Manufactures in New York made a report on the best way to preserve and increase the growth of timber. Four years afterwards Congress appropriated $\$ 200,000$ for the purchase and preservation of timberlands to supply ship timbers for the Navy, and in 1822 , with the same object in view, it authorized the President to employ the Army and Navy to protect and preserve the live oak and red cedar timber of the Government in Florida. Since that time more and more attention has been given to the forests. In 1828 Governor DeWitt Clinton, of New York, spoke of the reproduction of our woods as an object of primary importance, and in the same year the Government began an attempt to cultivate live oak in the South for the use 
of the Nary. Three years later an act was passed which is still almost the only protection for the much-abused forests of the public domain.

In 1872 the Yellowstone National Park was established, and in 1873 Congress passed the timber-culture act, which gave Government land in the treeless regions to whoever would plant one-fourth of his claim with trees. In 1875, the American Forestry Association was formed in Chicago through the efforts of Dr. John A. Warder, who was one of the first men to agitate forest questions in the United States. In the centennial year $(1876)$ Dr. Franklin B. Hough, perhaps the foremost pioneer of forestry in America, was appointed special agent in the Department of Agriculture. This was the beginning of educational work in forestry at Washington. Soon afterward Congress began to make appropriations to protect the public timber, but nothing was done to introduce conservative forest management. 'The present Bureau of Forestry in the Department of Agriculture was established as a division in 1881.

About this time forest associations began to be established in the different States, the most influential and effective of which has been that in Pennsylvania. 'The States also began to form forest boards or commissions of their own.

In 1885 the first forest bill was introduced in Congress. It failed to pass, but in 1891 an act was passed which was the first step toward a true policy for the forests of the nation. 'The first step toward national forestry is control of the national forests. This act, whose chief purpose was to repeal the timber-culture 
act, contained a clause which authorized the President to reserve timberlands on the public domain, and so prevent them from passing out of the possession of the Government.

THE PUBLIC DOMAIN.

In all the States and Territories west of the Mississippi except Texas, and in Ohio, Indiana; Illinois, Michigan, Wisconsin, Florida, Alabama, and Mississippi, all the land orginally belonged to the Government. This was the public domain. It has gradually been sold or given away until in many of the States it has all or nearly all passed to other owners. But it still includes more than $470,000,000$ acres, or nearly one-third of the United States, not including the Territory of Alaska, which has an area of about $350,000,000$ acres. A large part of the public domain has been surreyed by the Government and divided first into squares 6 miles on each side, called townships, then into squares of 1 mile, called sections, and these again into quarter sections and smaller divisions. The lines which mark these divisions are straight and at right angles to each other. When any part of the public domain is reserved or disposed of it is usually located by reference to these lines.

FEDERAL FOREST RESERVES.

When the President was given the power to make forest reserves, the public domain still contained much of the best timber in the West, but it was passing rapidly into private hands. Acting upon the wise prirciple that forests whose preservation is necessary for the general welfare should remain in Government con- 
trol, President Harrison created the first forest reserves. President Cleveland followed his example. But there was yet no systematic plan for the making or management of the reserves, which at that time were altogether without protection by the Government. Toward the end of President Cleveland's second Administration, therefore, the National Academy of Sciences was asked to appoint a commission to examine the national forest lands and report a plan for their control. The acadeny did so, and upon the recommendation of the National Forest Commission so appointed, President Cleveland doubled the reserved area by setting aside 13 additional forest reserves on Washington's Birthday, 1897 .

The Cleveland forest reserves awakened at once great opposition in Congress and thronghout the W est, and led to a general discussion of the forest policy. But after several years of controversy widespread approval took the place of opposition, and at present the value of the forest reserves is rarely disputed, except by private interests impatient of restraint.

The recommendations of the National Forest C'ommission for the management of the forest reserves were not acted upon by Congress, but the law of June 4,1897 , gave the secretary of the Interior authority to protect the reserves and make them useful. The passage of this law was the first step toward a national forest service. The second step was the act of Congress, approved February 1, 1905, which transferred the control of the national forest reserves from the Department of the Interior to the Department of Agriculture. This act consolidated the Government's forest work, which had been divided between the General Land Office and the Bureau of Forestry, and 
secured for the reserves the supervision of trained foresters.

President McKinley and after him President Roosevelt continued to make forest reserves. The latter introduced a system of examining the proposed forest reserves, so that now their boundaries are better located than ever before. Under him great progress has been made by the Government in bringing about the practice of forestry by forest owner's and in awakening the great lumber interests, as well as the people in general, to the dangers of forest destruction.

The forest reserves lie chiefly in high mountain regions. They are 62 in number, and cover an area (January 1, 1905) of 63,308,319 acres. They are useful first of all to protect the drainage basins of streams used for irrigation, and especially the watersheds of the great irrigation works which the Government is constructing under the reclamation law, which was passed in 1902. This is their most important use. Secondly, they supply grass and other forage for many thousands of grazing animals during the summer, when the lower ranges on the plains and deserts are barren and dry. Lastly, they furnish a permanent supply of wood for the use of settlers, miners, lumbermen, and other citizens. This is at present the least important use of the reserves, but it will be of greater consequence hereafter. 'The best way for the Government to promote each of these three great uses is to protect the forest reserves from fire.

STATE FORESTRY.

Many of the States have taken great and effective interest in forestry. Among those which have made 
most progress are New York and Pennsylvania. New York has a State forest preserve of $1,436,6 s 6$ acres, and Pennsylvania one of 700,000 acres. Michigan, Minnesota, and other States are rapidly following their example.

In 1892 the first example of systematic forestry in the United States was begun at Biltmore, in North Carolina. It is still in successful operation.

The first professional foresters in the United States were obliged to go ahroad for their training, but in 1898 professional forest schools were established at Cornell University in New York, and at Biltmore, in North Carolina, and they were followed by the Yale Forest School in 1900. Others have sprung up since. At present, thorough and efficient training in professional forestry can be had in the United States.

THE END.

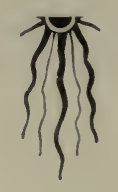




- 1





\section{Rare Book Cabint}

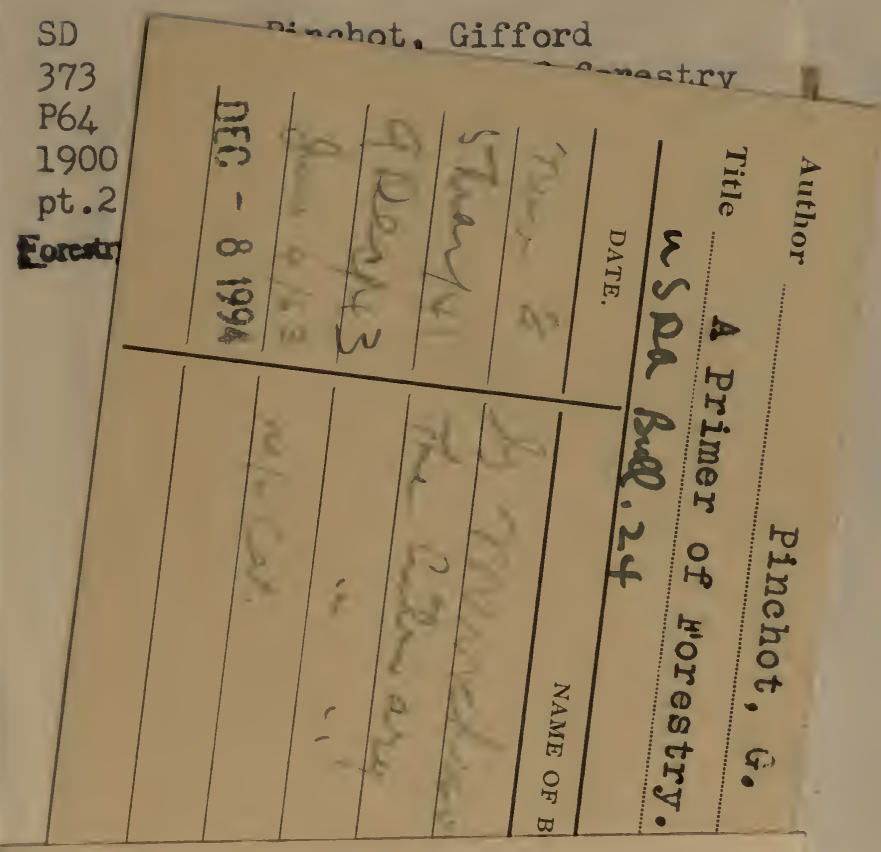

\section{PLEASE DO NOT REMOVE SLIPS FROM THIS POCKET}

$$
(9+712)
$$

\section{UNIVERSITY OF TORONTO LIBRARY}


